\title{
The Lords of the West: \\ Cloaking, Freedom and the Divine Narrative in Tolkien's Poetics
}

\section{Giuseppe Pezzini}

\section{Introduction: Where is 'God'?}

Where is 'God'? This question echoes throughout human history, amplified by the best of its literature, from Homer to Virgil, from Greek tragedy to Shakespeare. It is also a crucial interrogative in a book which has rightly been associated with these literary classics, ${ }^{1}$ Tolkien's The Lord of the Rings (LotR). That the God question has something to do with LotR is difficult to deny. Tolkien himself described LotR as having been 'built on or out of certain 'religious' ideas', ${ }^{2}$ focusing on a 'conflict about God', ${ }^{3}$ in sum as a 'fundamentally religious and Catholic work'. ${ }^{4}$ And yet 'religion' is apparently absent from the novel: in Lot $R$ there are apparently no references to cults, practices or fully divine entities, no praying or liturgy, no temples or churches, no priests or monks, religion, and above all not a single mention of the name of God.

This absence is of course an intentional authorial choice, as often emphasised by Tolkien in his letters. See, for example, this:

I have not put in, or have cut out, practically all references to anything like 'religion', to cults or practices in the imaginary world. For the religious element is absorbed into the story and the symbolism. ${ }^{5}$

Following Tolkien's words, many readers and scholars have tried to 'distil' the religious element from the story, and decode its Christian 'symbolism'; in doing so, they have often approached LotR, more or less intentionally, as a sort of religious allegory, focusing on the 'symbolic' meaning of events or characters, or reconstructing the moral or theological doctrine supposedly informing the narrative. ${ }^{6}$ Many scholars have highlighted, for instance, the Christ-

\footnotetext{
${ }^{1}$ Cf. Letter 156, to R. Murray, SJ, 2 December 1953, in J.R.R. Tolkien, The Letters of J. R. R. Tolkien, ed. Humphrey Carpenter (Boston: Houghton Mifflin, rev. ed., 2000), 201. (Henceforth, letters are cited by letter number, recipient, date, and page number in this volume.)

${ }^{2}$ Letter 211, to R. Beare, 14 October 1958, 283.

${ }^{3}$ Letter 183, to W. H. Auden, probably 1956, 243: 'In The Lord of the Rings the conflict is not basically about "freedom," though that is naturally involved. It is about God, and His sole right to divine honour. The Eldar and the Numenoreans believed in The One, the true God, and held worship of any other person an abomination. Sauron desired to be a God-King, and was held to be this by his servants; if he had been victorious he would have demanded divine honour from all rational creatures and absolute temporal power over the whole world.'

${ }^{4}$ Letter 142, to R. Murray, SJ, 2 December 1953, 172: 'The Lord of the Rings is of course a fundamentally religious and Catholic work.'

${ }^{5}$ Letter 142, to R. Murray, SJ, 2 December 1953, 172.

${ }^{6}$ The bibliography is mainly recent, but already extensive; cf. e.g. Joseph Pearce, Tolkien: Man and Myth (San Francisco: Ignatius Press, 1998); R.L. Purtill, J.R.R. Tolkien: Myth, Morality, and Religion (San Francisco: Ignatius, 2003); I. Boyd and S. Caldecott, A Hidden Presence (South Orange, NJ: Chesterton, 2003); R.C. Wood, The Gospel According to Tolkien (London: Westminster John Knox Press, 2003); C. Garbowski, Recovery and
} 
type figure of characters such as Gandalf, Sam, Frodo and Aragorn, ${ }^{7}$ the Eucharistic symbolism of the Elvish way-bread (lembas), ${ }^{8}$ the chronological correspondences between the novel's timeframe and the liturgical year, ${ }^{9}$ the Marian characterisation of Galadriel, ${ }^{10}$ and so on. More generally, a range of supposedly Christian 'values' or 'concepts' have been identified as figuratively embodied in the novel, from friendship to self-sacrifice, from redemption to mercy, from victory over temptation to ecology, to name just a few.

This approach is of course valuable and rewarding, but it is not the one I will take in this article. In fact, the subject of my opening question ('where is God?') is not the Christian God of Tolkien's 'primary reality', nor the theological or moral doctrines allegedly related to Him; my focus is rather on the 'God' within Tolkien's 'secondary plane', that is the 'God' of Middle Earth.

In fact, we know well that there is a God in Middle Earth, and actually more than one. A complex 'secondary' theology and cosmogony underpin Tolkien's imagined universe ('the secondary world'), which is openly and fully revealed in the Silmarillion. ${ }^{11}$ According to this, a single, superior Being (Eru or Ilúvatar) created a number of secondary divine powers (the Valar), with and through whom He subsequently brought into existence the World to which Middle Earth belongs (Arda or Eä). The Valar are embodied within Arda and, together with a race of angelic assistants (the Maiar), inhabit an Eden-like region (Valinor), situated in the Western side of Arda; because of this they are normally known as the 'Lords of the West'. In Arda the Valar 'exercise delegated authority in their spheres', ${ }^{12}$ including e.g. water, earth and wind, in a fashion similar to the Greek gods. From a narrative perspective, in the Silmarillion (and other works) the Valar are characters to all effects: they speak, they fight, they deliberate, they interact with each other and with the anthropomorphic races who live in Arda, including above all elves and men; elves and men are special object of the Valar's love and care, because

Transcendence for the Contemporary Mythmaker: The Spiritual Dimension in the Works of J. R. R. Tolkien (Zurich and Bern: Walking Tree Publishers, 2004); M.T. Dickerson, Following Gandalf(Ada, MI: Brazos Press, 2003); C. Filmer-Davies, 'Theology in The Lord of the Rings', in M.D.C. Drout (ed.), J.R.R. Tolkien Encyclopedia (New York: Routledge, 2007), 645-6; A. Milbank, Chesterton and Tolkien as Theologians (London: T\&T Clark, 2009); S. Caldecott, The Power of the Ring: The Spiritual Vision Behind the Lord of the Rings (New York: Crossroad Publishing, 2012), esp. 71-93; see also P. Pinsent, 'Religion: An Implicit Catholicism' in S. D. Lee (ed.), A Companion to J. R. R. Tolkien (London: Wiley-Blackwell, 2014), 446-60. For an overview of scholarship see B.J. Birzer, 'Christian Readings of Tolkien', in Drout (ed.), Encyclopedia, 99-101; M.T. Dickerson, 'Theological and Moral approaches in Tolkien's works', in Drout (ed.), Encyclopedia, 643-5; B. Rosebury, 'Tolkien in the History of Ideas', in H. Bloom (ed.), J.R.R. Tolkien (New York: Infobase Publishing, 2008), 89120. For criticism see e.g. P.E. Kerry, The Ring and the Cross: Christianity and The Lord of the Rings (Madison, WI: Fairleigh Dickinson University Press, 2011).

${ }^{7}$ Cf. e.g. P. Kreeft, The Philosophy of Tolkien (San Francisco, CA: Ignatius, 2005), 221-6; Caldecott, Power of the Ring, 51-5, 59-62.

${ }^{8}$ Cf. Caldecott, Power of the Ring, 86.

${ }^{9}$ Cf. e.g. T. Shippey, The Road to Middle-earth (Boston and New York: Houghton Mifflin, $2^{\text {nd }}$ ed., 2003), 227-

8; Caldecott, Power of the Ring, 81-3.

${ }^{10} \mathrm{Cf}$. Caldecott, Power of the Ring, 76-80.

${ }^{11}$ For an overview see Letter 131, to M. Waldman, late 1951; cf. also V. Flieger, Green Suns and Faërie: Essays on Tolkien (Kent, OH: Kent State University Press, 2012); V. Flieger, Splintered Light: Logos and Language in Tolkien's World (Kent, OH: Kent State University Press, $2^{\text {nd }}$ ed., 2002), 49-56; S. Caldecott, 'A New Light: Tolkien's Philosophy of Creation in The Silmarillion', The Journal of Inklings Studies 4, no 2 (2014), 67-85; G. Nagy, 'The Silmarillion: Tolkien's Theory of Myth, Text, and Culture', in Lee (ed.), Companion, 107-18; L. A. Donovan, 'Middle-earth Mythology: An Overview', in Lee (ed.), Companion, 92-106; L. Coutras, Tolkien's Theology of Beauty (London: Palgrave Macmillan, 2016).

${ }^{12}$ Letter 131, 146. 
they were created by Eru only, without any participation from them, and for this reason they are known as 'Children of Ilúvatar'. Eru/Ilúvatar does not inhabit Arda, and yet He does care about and at times intervenes in it, for instance by causing the Atlantis-like catastrophe at the end of the Silmarillion.

Eru/Ilúvatar and (secondarily) the Valar are also objects of religious veneration: most elves know and are devoted to them, and in fact many have lived together with them in Valinor, following an ancestral summoning by the Valar themselves. Men, too, know about the existence of the Valar; they 'believe' in and worship them, although few men have actually seen them in person; some men, and in particular the 'Elvenized' Numenoreans, even have a developed religious system dedicated to Eru and (secondarily) the Valar, which involves praying, temples, feasts, and sacrifices. ${ }^{13}$ This is not the place to discuss all the implications of this complex theology and religion, but it is enough to show that in the Silmarillion 'the divine' is an important narrative presence, even (and perhaps especially) when it is rejected by anthropomorphic races. In fact, the narrative core of the book, namely the quest for the ancestral jewels, the Silmarils, has itself a strong and explicit theological dimension: the Silmarils are creature-made artefacts, but their allure derives from the divine light which they conserve; because of this, the Silmarils are catastrophic to all who try to possess them while forgetting or rejecting their divine origin. ${ }^{14}$

LotR is set in the same world as the Silmarillion, although a few millennia in the future and in a different geographical region; it also features several characters who originally appeared in the Silmarillion, including above all Sauron, Galadriel and Elrond. The world is the same, and yet its 'religious' dimension, (explicitly) paraded in the Silmarillion, has (almost) completely been removed; above all, in Lot $R$ there is no (open) interaction whatsoever between gods and humans, no 'theophanies' of any sort. If God and the gods are still alive, they (apparently) have ceased to care about Middle Earth, and vice versa. The qualifiers which I have used in the previous sentence ('explicitly', 'almost', 'open', 'apparently') are of course crucial, and I will dedicate my article justifying their use (sections 1 and 2) and investigating their rationale in both the secondary and primary world (sections 3 and 4), with the ultimate aim of shedding light on Tolkien's complex, Christian views on what is literature and who is God.

\section{Explicit references to 'religion'}

In fact, there are a small number of explicit references to 'religion' in LotR. The people of Gondor in particular, who descend from the Numenoreans, preserve vestiges of their ancient

\footnotetext{
${ }^{13}$ Cf. also 'Near to the centre of the Mittalmar stood the tall mountain called Meneltarma, Pillar of the Heavens, sacred to the worship of Eru Ilúvatar... Thrice only in each year the King spoke, offering prayer for the coming year at the Erukyermë in the first days of spring, praise of Eru Ilúvatar at the Erulaitalë in midsummer, and thanksgiving to him at the Eruhantalë at the end of autumn'; J.R.R. Tolkien, Unfinished Tales of Númenor and Middle-earth, ed. Christopher Tolkien (Boston: Houghton Mifflin, 1980), 165.

${ }^{14}$ Cf. e.g. "he [i.e. the fallen Fëanor] seldom remembered now that the light within them [i.e. the Silmarils] was not his own; J.R.R. Tolkien, The Silmarillion, ed. Christopher Tolkien (London: Houghton Mifflin, 1977), 7, 69 (hereafter cited as Silmarillion followed by chapter and page numbers). On the symbolism of the Silmarils see e.g. Caldecott, Power of the Ring, 110.
} 
devotion to the Valar, although without a full understanding. ${ }^{15}$ During the battle against Eastern men, for instance, two Gondorian warriors openly invoke the Valar in battle with an apotropaic formula. ${ }^{16}$ Moreover, Gondorians keep the practice of having a grace-like moment of silence before meals, with the heard turned towards West, that is, as Faramir explains to the 'rustic and untutored' Frodo, 'towards Númenor that was, and beyond to Elvenhome that is, and to that which is beyond Elvenhome and will ever be' (i.e. Valinor). ${ }^{17}$ Finally, when Aragorn is enthroned as king, Gandalf appropriately associates his kingdom with that of the Valar. ${ }^{18}$

Apart from the Gondorians, elves too often invoke the protection of the Valar, and above all that of their Queen, named Varda or Elbereth. ${ }^{19}$ One short hymn to Elbereth is recorded in the Lord of the Rings, in two versions, ${ }^{20}$ as well as a song in which she is nostalgically addressed by Galadriel. ${ }^{21}$ Galadriel's song is sung in Elvish and, crucially, is not immediately understood by Frodo, but is only interpreted by him 'long afterwards', 'as well as he could'. ${ }^{22}$ This is an important feature of 'religion' in LotR: the Hobbits' default unfamiliarity with 'religion' and 'religiosity', together with their gradual introduction to these in the course of the novel. Frodo and Sam in particular gradually learn to cherish the name of Elbereth, and in three key moments (successfully) invoke her protection; in all cases, however, the narrator emphasises a degree of unconsciousness in the hobbits' act. $^{23}$

\footnotetext{
${ }^{15}$ Cf. also Letter 156, 206: 'So while God (Eru) was a datum of good Númenórean philosophy, and a prime fact in their conception of history, He had at the time of the War of the Ring no worship and no hallowed place. And that kind of negative truth was characteristic of the West, and all the area under Númenórean influence: the refusal to worship any 'creature', also We are in a time when the One God, Eru, is known to exist by the wise, but is not approachable save by or through the Valar, though He is still remembered in (unspoken) prayer by those of Númenórean descent... They [the Numenoreans]...preserved the vestige of thanksgiving. (Those under special Elvish influence might call on the angelic powers for help in immediate peril or fear of evil enemies).'

16 'May the Valar turn him aside'; J.R.R. Tolkien, The Lord of the Rings (London: HarperCollins, 2004), 4.4, 661 (hereafter cited as LotR followed by part and chapter, then page number).

17 Before they ate, Faramir and all his men turned and faced west in a moment of silence. Faramir signed to Frodo and Sam that they should do likewise. "So we always do," he said, as they sat down: "we look towards Númenor that was, and beyond to Elvenhome that is, and to that which is beyond Elvenhome and will ever be. [i.e. Valinor] Have you no such custom at meat?" "No," said Frodo, feeling strangely rustic and untutored' (LotR 4.5, 676).

18 'Now come the days of the King, and may they be blessed while the thrones of the Valar endure!' (LotR 6.5, 968).

${ }^{19}$ Cf. e.g. 'But my heart forbodes that, ere all is ended, you, Frodo son of Drogo, will know more of these fell things than Gildor Inglorion. May Elbereth protect you!' (LotR 1.3, 85). 'A sudden dread fell on the Company. "Elbereth Gilthoniel!" sighed Legolas as he looked up' (LotR 2.9, 387).

20 'Snow-white! Snow-white! O Lady clear! |... We still remember, we who dwell | In this far land beneath the trees | The starlight on the Western Seas' (LotR 1.3,79). 'A! Elbereth Gilthoniel! | silivren penna míriel | o menel aglar elenath, | Gilthoniel, A! Elbereth! |... The starlight on the Western Seas'. (LotR 6.9, 1028).

21 'Ai! laurië lantar lassi súrinen...Nai elyë hiruva. Namárië!' (LotR 2.8, 377-8).

22 'But now she sang in the ancient tongue of the Elves beyond the Sea, and he did not understand the words:...long afterwards he interpreted them, as well as he could: the language was that of Elven-song and spoke of things little known on Middle-earth. Ai! laurië lantar...' (LotR 2.8, 377).

23 'At that moment Frodo threw himself forward on the ground, and he heard himself crying aloud: O Elbereth! Gilthoniel!' (LotR 1.11, 195). 'Gilthoniel A Elbereth! And then his tongue was loosed and his voice cried in a language which he did not know: A Elbereth Gilthoniel o menel palan-diriel, le nallon sí di'nguruthos! A tiro nin, Fanuilos! And with that he staggered to his feet and was Samwise the hobbit, Hamfast's son, again' (LotR 4.10, 729-30). 'Gilthoniel, A Elbereth!' Sam cried. For, why he did not know, his thought sprang back suddenly to the Elves in the Shire, and the song that drove away the Black Rider in the trees. 'Aiya elenion ancalima!' cried Frodo once again behind him' (LotR 6.1,914).
} 
Elbereth is the wife of the Jupiter-like deity Manwë, the King of the Valar or 'Elder king', who is also mentioned once in LotR, in another song, sung by Bilbo in Rivendell. ${ }^{24}$ In fact, in LotR many of the (few) references to the Valar or their land (Valinor, the Blessed Realm, or the Uttermost West) are associated with Elves and/or songs, and have thus an esoteric aura to the hobbits. ${ }^{25}$ To these one can add a few other sparse instances, ${ }^{26}$ including in particular a simile comparing Theoden's ride to that of the Vala Oromë, ${ }^{27}$ for a total of less than twenty (more or less) explicit references to divine entities in LotR. A few others are found in the appendix, mainly in connection with events recounted in the Silmarillion; the only exception is a passing mention to Eru (the One), made by the elf-maid Arwen in her last dialogue with her husband Aragorn. ${ }^{28}$ Interestingly, this mention occurs in an almost 'defiant' passage, in which Arwen indirectly criticises Eru/Ilúvatar for demanding from men a blind trust in accepting the bitter gift of death, while He remains mute and distant. This is significant: all of the more or less explicit references to the divine in Lot $R$ belong to the human or elvish side of the relationship: elves or men may pray to the gods, but there is no explicit indication that the gods respond to them, that they are somehow 'active' in Middle Earth. God (or gods) remain silent.

These explicit 'religious' references are very few (less than twenty in total), and are scattered across LotR; given the size of the novel, they are like drops in the ocean, easily overlooked by the average reader: and yet, they are there, and shine like 'glimpses' of a hidden light, to introduce a key Tolkienian analogy, ${ }^{29}$ which will be central in my following argument.

\section{An invisible lamp: the hidden 'divine narrative'}

The light of the 'divine' (in a 'secondary' sense) is in fact much more prominent in LotR than these sparse glimpses may suggest, but it is a hidden, invisible, 'cloaked' presence. As put by an early reader of the book, quoted by Tolkien with approval, in Middle Earth 'some sort of faith seems to be everywhere without a visible source, like light from an invisible lamp' ${ }^{30} \mathrm{I}$

\footnotetext{
24 ، ... and seven lights before him sent, | as through the Calacirian | to hidden land forlorn he went. | He came unto the timeless halls where shining fall the countless years, and endless reigns the Elder King in Ilmarin on Mountain sheer' (LotR 2.1, 235).

${ }^{25}$ Cf. also Bilbo's song: 'He saw the Mountain silent rise where twilight lies upon the knees of Valinor, and Eldamar beheld afar beyond the seas' (LotR 2.1, 233-5). "A Elbereth Gilthoniel,... "It is a song to Elbereth," said Bilbo. "They will sing that, and other songs of the Blessed Realm, many times tonight. Come on!" (LotR 2.1, 238). 'And Frodo went to the King as he was sitting with the Queen Arwen by the fountain, and she sang a song of Valinor, while the Tree grew and blossomed' (LotR 6.6, 974). On the 'mystic' power of poetry and poetic imagination in Tolkien see e.g. Caldecott, Power of the Ring, esp. chapter 1.

26 'Good night! I'll take a walk, I think, and look at the stars of Elbereth in the garden. Sleep well!' (LotR 2.1, 238). '...the seed of that tree before came from Eressëa, and before that out of the Uttermost West in the Day before days when the world was young' (LotR 2.2, 245).

27 'Fey he seemed, or the battle-fury of his fathers ran like new fire in his veins, and he was borne up on Snowmane like a god of old, even as Oromë the Great in the battle of the Valar when the world was young' (LotR 5.5, 838). 28 'For if this is indeed, as the Eldar say, the gift of the One to Men, it is bitter to receive' (LotR Appendix A, 1036).

${ }^{29}$ Cf. e.g. 'This tale grew in the telling, until it...included many glimpses of the yet more ancient history that preceded it' (LotR Introduction, xviii, and the passages quoted below in section 4.3 and 4.4). Also Letter 156, to R. Beare, 14 October 1958, 201 (quoted below, section 4).

${ }^{30}$ Letter $328,413$.
} 
will now try to draw this lamp into the open, although not completely, since I am well aware that Tolkien would probably disapprove of the exercise. ${ }^{31}$

\subsection{The Eagles of the Lords of the West}

I will first focus on a passage which is perhaps the brightest glimpse of all, and in fact, if correctly understood, the most explicit revelation of the hidden narrative running in the background of LotR (what I will henceforth call 'the divine narrative'); at least to my knowledge, this reference has never been properly interpreted and spotlighted.

In the denouement of the story, after the ring has been destroyed and Frodo and Sam have been rescued and celebrated in the Fields of Cormallen, the news of the unexpected victory has still to reach the city of Minas Tirith. But this is soon made up for:

And before the Sun had fallen far from the noon out of the East there came a great Eagle flying, and he bore tidings beyond hope from the Lords of the West: 'Sing now ye people of Minas Anor for the realm of Sauron is ended for ever and the Dark Tower is thrown down.... 32

Who are the 'Lords of the West', who send a winged messenger to announce 'tidings beyond hope' to the city of men? Inattentive readers may take this epithet as referring to Aragorn and the other 'Captains of the West', who had victoriously led 'the host of the West' against Mordor. But this cannot be the case. As mentioned, in the Silmarillion the 'Lords of the West' is the standard epithet of the Valar, attributable to no other being. In fact, in the Appendices to LotR and Unfinished Tales, it is explicitly stressed that appropriating that divine epithet is tantamount to blasphemy:

The twentieth King took his royal name, in Númenórean form, calling himself Ar-Adûnakhôr, 'Lord of the West'. This seemed ill-omened to the Faithful, for hitherto they had given that title only to one of the Valar, or to the Elder King himself. ${ }^{33}$

But these titles were held by the Faithful to be blasphemous, for they signified 'Lord of the West', by which title they had been wont to name one of the great Valar only, Manwë in especial. ${ }^{34}$

The divine identity of the 'Lords of the West' is further suggested by the standard association of the eagles with the Valar, and especially with their king Manwë. ${ }^{35}$ Indeed, as revealed in the Silmarillion:

\footnotetext{
${ }^{31}$ Cf. 'I do not (of course) know the truth of the matter [i.e. about Gandalf's identity], and if I did it would be a mistake to be more explicit than Gandalf' (Unfinished Tales, 395).

${ }^{32} \operatorname{LotR} 6.5,963$.

${ }^{33}$ LotR Appendix A, 1036.

${ }^{34}$ Unfinished Tales, 222.

${ }^{35}$ Cf. e.g. 'Then men grew afraid. 'Behold the Eagles of the Lords of the West!' they cried. 'The Eagles of Manwë are come upon Númenor!' And they fell upon their faces.... Then the Eagles of the Lords of the West came up out of the dayfall, and they were arrayed as for battle, advancing in a line the end of which diminished
} 
The shape of hawks and eagles flew ever to and from his [i.e. Manwë's] halls; and their eyes could see to the depths of the seas, and pierce the hidden caverns beneath the world. Thus they brought word to him of well nigh all that passed in Arda. ${ }^{36}$

For Manwë to whom all birds are dear, and to whom they bring news upon Taniquetil from Middle-earth, had sent forth the race of Eagles, commanding them to dwell in the crags of the North, and to keep watch upon Morgoth; for Manwë still had pity for the exiled Elves. And the Eagles brought news of much that passed in those days to the sad ears of Manwë. ${ }^{37}$

In the Silmarillion, eagles are thus explicitly described as divine entities, dispatched by Manwë to Middle Earth as emissaries of his pity, to guard, ${ }^{38}$ protect, ${ }^{39}$ and in some cases physically rescue the beloved elves or men. ${ }^{40}$ Although their divine identity is never revealed, eagles are also active in the Hobbit and LotR, where they are characterized as bringers of hope in the most desperate circumstances: eagles rescue Bilbo and his companions from the fire of the Orcs in the Hobbit, and later intervene to help to secure the victory in the Battle of the Five Armies; an eagle rescues Gandalf twice in LotR, once from the prison of Isengard and later from the top of the mountains above Moria; above all, it is only thanks to the eagles that Sam and Frodo can be rescued from the destruction of Mordor, just when the two hobbits are 'stricken down by despair at last'. ${ }^{41}$

In Tolkien's world, eagles are thus rescuers, (more or less explicitly) sent by the Valar out of their love for elves and men (and hobbits), to bring hope when all hope is lost. ${ }^{42}$ There can

beyond sight; and as they came their wings spread ever wider, grasping the sky' (Silmarillion, 277). Cf. Caldecott 2012: 44-5.

36 Silmarillion, 40.

${ }^{37}$ Silmarillion, 110.

${ }^{38} \mathrm{Cf}$. '[The eagles] were called the Witnesses of Manwë, and they were believed to be sent by him from Aman to keep watch upon the Holy Mountain and upon all the land [i.e. of Númenor]' (Unfinished Tales, 166).

39 For instance, the hidden city of Gondolin was preserved safe for many years only thanks to the eagles' surveillance of its borders.

${ }^{40}$ Cf. e.g. 'Now, even as Fingon bent his bow, there flew down from the high airs Thorondor, King of Eagles, mightiest of all birds that have ever been, whose outstretched wings spanned thirty fathoms; and staying Fingon's hand he took him up, and bore him to the face of the rock where Maedhros hung' (Silmarillion 13, 110); 'There Thorondor espied them, and he sent two of his eagles to their aid; and the eagles bore them up and brought them beyond the Encircling Mountains (Silmarillion 18, 158). 'But the eagles coming stooped upon the Orcs, and drove them shrieking back; and all were slain or cast into the deeps, so that rumour of the escape from Gondolin came not until long after to Morgoth's ears' (Silmarillion 23, 243).

${ }^{41}$ LotR 6.4, 952.

${ }^{42}$ Eagles have an important connection with one of the key notions of Tolkien's literary theory (and theology), that is eucatastrophe (cf. Caldecott, Power of the Ring, 45): cf. Letter 89, to Christopher Tolkien, 7-8 November 1944, 101: 'I had suddenly in a fairly strong measure the "eucatastrophic" emotion at Bilbo's exclamation: "The Eagles! The Eagles are coming!".' Eucatatrophe is 'the sudden joyous "turn"' against all expectations, in which 'we see in a brief vision that the answer may be greater - it may be a far-off gleam or echo of evangelium in the real world'; J.R.R. Tolkien, 'On Fairy Stories', in idem, The Monsters and the Critics and other Essays, ed. Christopher Tolkien (London: HarperCollins, 2006), 155; see e.g. Flieger, Splintered Light, 21-32; T. Shippey, J. R. R. Tolkien: Author of the Century (London: Houghton Mifflin, 2011), 206-211. Eagles are also allusively associated with the Fellowship of the ring: for instance, the silver brooch given to all the members of the Fellowship by Galadriel was wrought in the likeness of an eagle. On the eagles as creatures 'with a suggestion of 
be little doubt therefore that the 'Lords of the West' sending messengers of 'tidings beyond hope ${ }^{43}$ are the same Valar of the Silmarillion, hidden presences who are also active in LotR, despite how things might appear to the inhabitants of Middle Earth. ${ }^{44}$

\subsection{Dreams and Inspiration}

The Valar (and Eru) do in fact care for Middle Earth, and their activity in LotR is an important narrative secret of the novel (the 'divine narrative'). ${ }^{45}$ This activity goes well beyond dispatching messengers. As in classical Epic, another important way in which the Valar interact with the characters is through dreams. In the Silmarillion it is explicitly revealed that Valar guide the history of elves and men by sending dreams with momentous implications. ${ }^{46}$ Lot $R$ too features several dreams, no less significant from a narrative perspective; these dreams have most likely the same divine origin, although only allusively declared. The most important case is the dream sent to Faramir and Boromir, to summon them to Rivendell. This is how Boromir recalls this key dream during the Council of Elrond:

For on the eve of the sudden assault a dream came to my brother in a troubled sleep;... but in the West a pale light lingered, and out of it I heard a voice... ${ }^{47}$

Given the association between the Valar and the West, there is little doubt about the identity of the 'pale light in the West'. ${ }^{48}$ The same divine origin is alluded to in the important dreams of Frodo, but I will leave the full discussion of this to another occasion.

Another analogous pattern in which the Valar participate in the narratives is what one might call 'inspiration'. Again, in the Silmarillion this form of intervention is explicitly attributed to the Valar, ${ }^{49}$ whereas in Lot $R$ this attribution is hidden, and yet allusively hinted at. There are several examples to illustrate this, but I will focus on two in particular: ${ }^{50}$

transcendence' see e.g. F. Rutledge, The Battle for Middle-earth: Tolkien's Divine Design in the Lord of the Rings (Grand Rapids, MI: Eerdmans, 2004), 29-43, 340-1.

${ }^{43}$ The divine origin of eagles is also confirmed by nature of the song, which, as Shippey, Road to Middle Earth, 226-7 notes, is heavily based on Psalmic diction, approaching the 'edge of Christian reference' and making allegory 'all but break through'.

${ }^{44} \mathrm{Cf}$. 'For surely the Valar are now removed and Middle-earth is far from their thought, and all who cling to it are under a shadow.' 'It is not so,' said Olórin. 'Their eyes are not dimmed nor their hearts hardened. In token of which look upon this!' (Unfinished Tales, 250).

45 See e.g. Rutledge, Battle for Middle-earth, for a reconstruction of this divine narrative, although from a theological, rather than literary perspective; also Garbowski, Recovery and Transcendence.

${ }^{46} \mathrm{Cf}$. 'For messages and dreams had come to him up Sirion from the sea, from Ulmo, Lord of Waters, warning him of woe to come and counselling him to deal kindly with the sons of the house of Hador, from whom help should come to him at need' (Silmarillion 18, 158).

${ }^{47}$ LotR 2.2, 246.

${ }^{48} \mathrm{Cf}$. also 'For he believed that the message of the dreams was a summons' (LotR 2.8, 368).

${ }^{49} \mathrm{Cf}$. e.g. 'Ulmo set it in his heart to depart from the land of his fathers, for he had chosen Tuor as the instrument of his designs' (Silmarillion, 238).

${ }^{50} \mathrm{Cf}$. also 'Then greatly daring, because he could think of nothing else to do, answering a sudden thought that came to him' (LotR 6.1, 902). 'And then suddenly new strength rose in him, and his voice rang out, while words of his own came unbidden to fit the simple tune' (LotR 6.1,908). 'Suddenly a sense of urgency which he did not understand came to Sam. It was almost as if he had been called: "Now, now, or it will be too late!" He braced himself and got up. Frodo also seemed to have felt the call. He struggled to his knees' (LotR 6.3, 942). 
At last with an effort he spoke, and wondered to hear his own words, as if some other will was using his small voice. 'I will take the Ring,' he said, 'though I do not know the way. ${ }^{51}$

And then softly, to his own surprise, there at the vain end of his long journey and his grief, moved by what thought in his heart he could not tell, Sam began to sing. ${ }^{52}$

The first passage is about Frodo's momentous decision to take the ring, which Tolkien describes as a free individual choice, and yet involving the participation of 'some other will', to the hobbit's 'wonder'. That this is the will of the Valar is suggested by Elrond's reaction to Frodo's words ('I think that this task is appointed for you, Frodo'), which evokes an important idea of the novel, that Frodo has been 'chosen' by the Valar (or perhaps Eru Himself) as the ring-bearer (see below 2.6).

The second passage is from one of the most desperate moments of the story, when the hobbit Sam is locked out of the floor where Frodo is trapped, in the dreadful tower of Cirith Ungol. Sam's act, which is 'surprising' to himself, will lead to a positive outcome, that is Frodo's rescue. That the Valar are behind Sam's 'musical inspiration' is suggested by the content of the song: a hymn about the permanence of Valinor, and the divine light of the Silmarils.

Dreaming and inspiration are important forms of divine intervention in LotR, and have an ancestry in Greek and Roman epic poems; but, again, the Valar's intervention in LotR does not consist only in sending messages or inspiring brave deeds.

\subsection{The (West) Wind}

In fact, the Valar also intervene through the natural powers of their competence, ${ }^{53}$ as a casestudy, I will here focus on wind, which is the element under the power of the 'Elder King' of the Valar, Manwë. In LotR the wind, often qualified as the Wind of the West, normally blows in concomitance with positive turns in the story. For instance, it is thanks to a 'West Wind' that the hobbits survive their first encounter with the Black riders, ${ }^{54}$ and it is the same West Wind which blows away the dark storm of Mordor, carries Aragorn's sails to the victory of Pelennor, ${ }^{55}$ and later accompanies the march of the host of the West towards the gate of

\footnotetext{
${ }^{51}$ LotR 2.2, 270.

${ }^{52}$ LotR 6.1, 908.

${ }^{53}$ Water (under the control of the Vala Ulmo) also plays an important role in Tolkien's universe, as a means to evoke in elves the desire for the Valar; cf. 'And it is said by the Eldar that in water there lives yet the echo of the Music of the Ainur more than in any substance else that is in this Earth; and many of the Children of Ilúvatar hearken still unsated to the voices of the Sea, and yet know not for what they listen' (Silmarillion, 19). See further, with caution, the preliminary study by R.M. Auer, 'Sundering Seas and Watchers in the Water: Water as a Subversive Element in Middle-Earth', in D. Fimi and T. Honegger (edd.), Sub-creating Arda: World-building in J.R.R. Tolkien's Work, its Precursors, and its Legacies (Zurich and Bern: Walking Tree Publishers, 2019), 237259.

54 'The wind's in the West' (LotR 1.3, 71). 'The West wind was sighing in the branches. Leaves were whispering. A star came out above the trees in the darkening East before them. After a time, as the stars grew thicker and brighter, the feeling of disquiet left them, and they no longer listened for the sound of hoofs' (LotR 1.3, 77).

55 'It was even as the day thus began to turn against Gondor and their hope wavered that a new cry went up in the City, it being then mid-morning, and a great wind blowing, and the rain flying north, and the sun shining' (LotR 5.6, 846); 'black against the glittering stream they beheld a fleet borne up on the wind. (LotR 5.6, 846) But the
} 
Mordor, clearing its foul air. ${ }^{56}$ Conversely, it is a 'great wind' that annihilates the crumbling power of Sauron, ${ }^{57}$ and later carried away the spirit of Saruman after his death. ${ }^{58}$

All this wind-blowing should not be construed symbolically, but narratively: as revealed in the Silmarillion, the Vala Manwë is physically in control of the winds which blow over Middle Earth. ${ }^{59}$ When the wind blows in LotR, and especially from the West, there is little doubt about its divine origin. This is further confirmed by the metaphorical association of the West Wind with the most important representative of the Valar's (hidden) power in Middle Earth, that is the wizard Gandalf:

'Were the breath of the West Wind to take a body visible, even so would it appear,' said Éomer, as the great horse ran up, until he stood before the wizard. ${ }^{60}$

'You thought I remained in Meduseld bent like an old tree under winter snow. So it was when you rode to war. But a west wind [i.e. Gandalf] has shaken the boughs. ${ }^{61}$

In fact, Gandalf himself is of course a (hidden) divine entity, a member of the Valar's people (the Maiar), a sort of 'incarnate angel', in Tolkien's definition, ${ }^{62}$ who, at the Valar's orders, was sent from Valinor to Middle Earth to rekindle hope and bravery, to lead the victory over Sauron, and ultimately to communicate (although covertly) 'the 'glad tidings' that the power of Ilúvatar is there and it endures', as well put by Nagy ${ }^{63}$.

wind that sped the ships blew all their clamour away' (LotR 5.6, 847); 'So he rode to a green hillock and there set his banner, and the White Horse ran rippling in the wind' (LotR 5.6, 847).

56 'The wind of the world blew now from the West, and the great clouds were lifted high, floating away eastward; but still only a grey light came to the dreary fields of Gorgoroth' (LotR 6.2, 923). 'A strong wind from the West was now driving the fumes of Mordor from the upper airs' (LotR 6.2, 927). ' ...for in the high regions the West Wind still blew' (LotR 6.3, 933). Cf. also Aragorn's allusive song, wishing for a return of a blessed kingdom: 'Shall Men behold the Silver Tree, | Or West Wind blow again between the Mountains and the Sea?' (LotR 3.2, 423).

57 'And as the Captains gazed south to the Land of Mordor, it seemed to them that, black against the pall of cloud, there rose a huge shape of shadow, impenetrable, lightning-crowned, filling all the sky. Enormous it reared above the world, and stretched out towards them a vast threatening hand, terrible but impotent: for even as it leaned over them, a great wind took it, and it was all blown away, and passed' (LotR 6.4, 949).

58 'For a moment it wavered, looking to the West; but out of the West came a cold wind, and it bent away, and with a sigh dissolved into nothing' (LotR 6.8, 1020).

${ }^{59} \mathrm{Cf}$. 'of the airs and winds Manwë most had pondered, who is the noblest of the Ainur' (Silmarillion, 19); 'Manwë is dearest to Ilúvatar and understands most clearly his purposes. He was appointed to be, in the fullness of time, the first of all Kings: lord of the realm of Arda and ruler of all that dwell therein. In Arda his delight is in the winds and the clouds, and in all the regions of the air, from the heights to the depths, from the utmost borders of the Veil of Arda to the breezes that blow in the grass' (Silmarillion, 26); 'above the roaring of the seas he heard the voice of Manwë as a mighty wind' (Silmarillion, 36); the winds of Manwë had driven away the vapours of death and rolled back the shadows of the sea; The rushing of the wings of Thorondor was like the noise of the winds of Manwë' (Silmarillion, 154).

${ }^{60}$ LotR 3.6, 524.

${ }^{61} \operatorname{LotR} 3.7,527$.

${ }^{62}$ Letter 156, to R. Murray, SJ, 4 November 1954, 202: 'I would venture to say that he [Gandalf[ was an incarnate "angel" - strictly an aggelos...'

${ }^{63}$ G. Nagy, 'On No Magic in Tolkien: Resisting the Representational Criteria of Realism', in D. Fimi and T. Honegger (edd.), Sub-creating Arda: World-building in J.R.R. Tolkien's Work, its Precursors, and its Legacies (Zurich and Bern: Walking Tree Publishers, 2019), 167. 


\subsection{Gandalf the Emissary}

Gandalf's divine identity and his 'intermediary' mission are revealed openly in Tolkien's Unfinished Tales, in a number of incomplete narratives:

Manwë, however, even after the Downfall of Númenor and the breaking of the old world, even in the Third Age when the Blessed Realm had been removed from the 'Circles of the World', was still not a mere observer. It is clearly from Valinor that the emissaries came who were called the Istari (or Wizards), and among them Gandalf, who proved to be the director and coordinator both of attack and defence. ${ }^{64}$

Emissaries they [i.e. the wizards] were from the Lords of the West, the Valar, who still took counsel for the governance of Middle-earth, and when the shadow of Sauron began first to stir again took this means of resisting him. For with the consent of Eru they sent members of their own high order, but clad in bodies as of Men, real and not feigned...their emissaries were forbidden to reveal themselves in forms of majesty, or to seek to rule the wills of Men or Elves by open display of power, but coming in shapes weak and humble were bidden to advise and persuade Men and Elves to good, and to seek to unite in love and understanding all those whom Sauron, should he come again, would endeavour to dominate and corrupt. ${ }^{65}$

The last-comer was named among the Elves Mithrandir [i.e. Gandalf], the Grey Pilgrim.... Warm and eager was his spirit...for he was the Enemy of Sauron, opposing the fire that devours and wastes with the fire that kindles, and succours in wanhope and distress; but his joy, and his swift wrath, were veiled in garments grey as ash, so that only those that knew him well glimpsed the flame that was within.... When Sauron rose again, he [Gandalf] also arose and partly revealed his power, and becoming the chief mover of the resistance to Sauron was at last victorious, and brought all by vigilance and labour to that end which the Valar under the One that is above them had designed. ${ }^{66}$

These passages are taken from different versions of the narrative, which yet all agree in presenting a 'hidden' narrative (the 'divine narrative') according to which Eru/Ilúvatar

\footnotetext{
${ }^{64}$ Unfinished Tales, 389.

${ }^{65}$ Unfinished Tales, 390.

${ }^{66}$ Unfinished Tales, 390.
} 
'designed' the plot of LotR, bearing His design to fulfilment through His intermediaries, the Valar first ${ }^{67}$ and then their emissaries in Middle Earth, including above all Gandalf. ${ }^{68}$

Just like the hidden power of the wizard, this divine narrative and Gandalf's role played in it, is never revealed in open terms in LotR, and yet it is often alluded to, for example in these self-descriptions by Gandalf:

'I am a servant of the Secret Fire, wielder of the flame of Anor. You cannot pass. ${ }^{69}$

'Olórin I was in my youth in the West that is forgotten.' 70

[to the overbearing and despairing Denethor:] 'For I also am a steward. Did you not know? ${ }^{71}$

And Aragorn, speaking at his coronation, says: 'In token of this I would have the Ring-bearer bring the crown to me, and let Mithrandir set it upon my head, if he will; for he has been the mover of all that has been accomplished, and this is his victory. ${ }^{72}$

The elusiveness of these references is often explicitly remarked upon, especially through the insistence on the motif of the 'cloaking' or 'veiling' of Gandalf's power.

Before him stooped the old figure, white, shining now as if with some light kindled within, bent, laden with years, but holding a power beyond the strength of kings. ${ }^{73}$

Pippin perceived that Gandalf had the greater power and the deeper wisdom, and a majesty that was veiled. ${ }^{74}$

Then Gandalf revealed the strength that lay hid in him, even as the light of his power was hidden under his grey mantle. ${ }^{75}$

\footnotetext{
${ }^{67}$ On the Valar as intermediaries of Eru cf. e.g. 'Such gifts as come from the Valar, and through them from the One, are to be loved for themselves now, and in all nows. They are not given for barter, for more or for better' (Unfinished Tales, 184). On the Valar as sub-creators cf. B. Rosebury, Tolkien: A Cultural Phenomenon (New York: Palgrave Macmillan, 2003), 189.

${ }^{68}$ Cf. Letter 156, to R. Murray, SJ, 4 November 1954, 207: 'The istari...are actually emissaries from the True West and so mediately from God, sent precisely to strengthen the resistance of the "good," when the Valar become aware that the shadow of Sauron is taking shape again.'

${ }^{69} \operatorname{LotR} 2.5,330$.

${ }^{70} \operatorname{LotR} 4.5,670$.

${ }^{71} \operatorname{LotR} 5.1,758$.

${ }^{72}$ LotR 6.5, 968 .

${ }^{73} \operatorname{LotR} 4.5,501$.

${ }^{74} \operatorname{Lot} R 5.1,757$.

${ }^{75}$ LotR 5.7, 852. Only at times Gandalf's power is (partially) 'unveiled'; cf. e.g. 'Shadowfax bore him, shining, unveiled once more, a light starting from his upraised hand' (LotR 5.4, 820).
} 
Gandalf's (divine) identity is indeed also hidden to most characters, and is a source of wonder:

What was Gandalf? In what far time and place did he come into the world, and when would he leave it? ${ }^{76}$

Elusiveness and allusiveness themselves are also important traits of Gandalf's characterization: Gandalf's speech and behaviour are full of riddles, omissions, hints, and are perceived as such by characters.

'But I am not going to give an account of all my doings to you.'

'Thence by strange roads I came.' 78

'Well, if Gandalf has changed at all, then he's closer than ever that's all., ${ }^{, 79}$

\subsection{Chance, fortune, providence}

Gandalf's speech is allusive and elusive not just as regards his own identity, but also as regards his interpretation of the events unfolding in the story, which his (divine) eyes recognize as belonging to and being guided by the 'divine narrative' designed by His Masters. A recurring formula in this respect is Gandalf's allusive qualification of the notion 'chance' or 'fortune'. See for example the following:

'You have been saved, and all your friends too, mainly by good fortune, as it is called. ${ }^{80}$

[Gandalf speaking] 'I did no more than follow the lead of "chance", and made many mistakes on the way. ${ }^{81}$

'A chance-meeting, as we say in Middle-earth.' 82

\footnotetext{
${ }^{76} \operatorname{LotR} 5.1,757$.

${ }^{77}$ LotR 1.2, 56 (original emphasis).

${ }^{78} \operatorname{LotR} 3.5,503$.

${ }^{79}$ LotR 3.11, 590. Cf. also '[b]ut he's [Gandalf] close, isn't he? Not changed at all. (...) Well, if Gandalf has changed at all, then he's closer than ever that's all' (LotR 3.11, 590); 'But what I knew in my heart, or knew before I stepped on these grey shores: that is another matter. Olórin I was in the West that is forgotten, and only to those who are there shall I speak more openly' (Unfinished Tales, 330); "If it is full. I do not really suppose that even now you are telling us all you know." "Of course not," said Gandalf' (Unfinished Tales, 336).

${ }^{80}$ LotR 3.11, 594.

${ }^{81}$ Unfinished Tales, 322.

${ }^{82}$ Unfinished Tales, 326. Cf. also "“Yes, fortune or fate have helped you," said Gandalf, "not to mention courage"”; LotR 2.1, 222.
} 
So it was 'by chance' as Men call it (as Gandalf would have said) that Peregrin, fumbling with the Stone, must have set it on the ground more or less 'upright'. ${ }^{83}$

Gandalf often relates a positive turn of action in the narrative to 'chance' or 'fortune', and yet he normally qualifies it with a remark of the kind 'as it is called' or similar. This kind of qualification can be construed as an allusive reference to the hidden 'divine narrative' described above: a divine entity like Gandalf knows well that 'chance' is an imprecise human word, ${ }^{84}$ used by unaware humans to refer to what is in fact the providential plan of Eru and the Valar. That is to say, Gandalf knows that there are 'powers at work' in Middle Earth, although he never openly reveals their identity. In particular, the finding of the ring, which is (outwardly) described by human characters as a 'lucky' event, ${ }^{85}$ is often described by Gandalf as the work of 'something else':

'Behind that there was something else at work, beyond any design of the Ring-maker. I can put it no plainer than by saying that Bilbo was meant to find the Ring, and not by its maker. In which case you also were meant to have it. And that may be an encouraging thought. ${ }^{86}$

Who is this 'something else at work', who chose 'Bilbo' as the Ring-finder? This very question is openly put to Gandalf in Unfinished Tales:

'But who wove the web?... Did you plan all this then, Gandalf?.... To find the Ring and bring it far away into the West for hiding, and then to choose the Ringbearer... was not that your design?' Gandalf did not answer at once. He stood up, and looked out of the window, west, seawards; and the sun was then setting, and a glow was in his face.... 'In that far distant time I said to a small and frightened hobbit: Bilbo was meant to find the Ring, and not by its maker, and you therefore were meant to bear it. And I might have added: and I was meant to guide you both to those points. ${ }^{97}$

Gandalf's answer is elusive, but his act of looking 'west, seawards' (i.e. to the Land of the Valar, who sent Him), is clear enough, just as his final words ('only to those who are there [in the West] shall I speak more openly').

\footnotetext{
${ }^{83}$ Unfinished Tales, 410.

${ }^{84}$ On the imperfections or corruptions of language, and on Tolkien's philosophy of language in general see Flieger, Splintered Light, esp. 33-44, 67-72.

${ }^{85}$ Cf. e.g. 'I am the friend of bears and the guest of eagles. I am Ringwinner and Luckwearer'; J.R.R. Tolkien, The Hobbit (London: HarperCollins, 1995) [ ${ }^{\text {st }}$ edition 1937, $2^{\text {nd }}$ revised edition 1951], 12, 258 (hereafter cited as Hobbit followed by chapter and page number); 'He put it [the ring] in his pocket. It seemed then like mere luck.... In the end Bilbo won the game, more by luck (as it seemed)... and once more he was saved by his luck' (LotR Prologue, 11-12).

${ }^{86}$ LotR 1.2, 56.

${ }^{87}$ Unfinished Tales, 329.
} 


\subsection{Narrative and Election}

As the passage quoted above (LotR 1.2) reveals ('you also were meant to have it'), another key implication of the 'divine narrative', of which Gandalf is aware of, is the idea of 'election' or 'vocation': Eru and the Valar are 'plotting' to overrule Sauron, but this involves the participation of human (and elvish) characters, who are called to identify and adhere to this plot. Gandalf is the perfect embodiment of this 'elective' attitude to (hi)story, which is first revealed in his capacity to wonder at the 'strange' turns of the unfolding narrative, and at the way apparent misfortunes are mysteriously transformed into positive events.

'I was delayed,' said Gandalf, 'and that nearly proved our ruin. And yet I am not sure: it may have been better so. ${ }^{, 88}$

'But at this time we have been strangely fortunate. Maybe, I have been saved by this hobbit from a grave blunder. ${ }^{89}$

'Then is not Saruman a traitor?' said Gimli. 'Indeed yes', said Gandalf. 'Doubly. And is not that strange?... Between them our enemies have contrived only to bring Merry and Pippin with marvellous speed, and in the nick of time, to Fangorn, where otherwise they would never have come at all!'90

This kind of remark is rooted in Gandalf's implicit awareness of the presence of a (hidden) providential narrative, woven by 'something else', which he himself is trying to acknowledge and interpret, in order to facilitate and adhere to it. Gandalf has thus an almost meta-literary 'elective' attitude to (hi)story, with which he strives to familiarize the Hobbits:

'Why did it come to me? Why was I chosen?' 'Such questions cannot be answered,' said Gandalf. 'You may be sure that it was not for any merit that others do not possess: not for power or wisdom, at any rate. But you have been chosen, and you must therefore use such strength and heart and wits as you have. ${ }^{91}$

Gandalf is not the only character who is aware of the 'divine' narrative hidden behind the events of LotR. The most 'enlightened' characters of the story are also aware of the importance of 'fate', and consequently of the importance of adhering to their own 'vocation' in relation to that fate. These include above all Elrond, Galadriel, Aragorn, and many others, including, eventually, the hobbits. who interpret events as 'hints' or signs of a deeper, hidden narrative.

\footnotetext{
${ }^{88} \operatorname{LotR}, 2.1,220$.

${ }^{89} \operatorname{LotR} 2.11,595$.

${ }^{90}$ LotR 3.5, 497.

${ }^{91}$ LotR 1.2, 61.
} 
[Gildor:] 'Our paths cross theirs seldom, by chance or purpose. In this meeting there may be more than chance; but the purpose is not clear to me, and I fear to say too much.' 92

[Tom Bombadil:] 'Just chance brought me then, if chance you call it. It was no plan of mine, though I was waiting for you.' ${ }^{93}$

[Elrond:] 'That is the purpose for which you are called hither. Called, I say, though I have not called you to me, strangers from distant lands. You have come and are here met, in this very nick of time, by chance as it may seem. Yet it is not so. Believe rather that it is so ordered that we, who sit here, and none others, must now find counsel for the peril of the world. Our paths cross theirs seldom, by chance or purpose. In this meeting there may be more than chance; but the purpose is not clear to me, and I fear to say too much. ${ }^{94}$

[Galadriel:] 'Maybe the paths that you each shall tread are already laid before your feet, though you do not see them.' 95

[Aragorn:] 'I at least have a mind to stand in that high place again, before I decide my further course. There, maybe, we shall see some sign that will guide us. ${ }^{96}$

[Faramir:] 'If you seem to have stumbled, think that it was fated to be so. Your heart is shrewd as well as faithful, and saw clearer than your eyes. ${ }^{97}$

Even the narrator himself at times evokes the idea of a providential plan:

It [i.e. the arrow killing the Orc Grishnákh and saving Merry and Pippin] was aimed with skill, or guided by fate, and it pierced his right hand. ${ }^{98}$

The more characters are aware of Eru and/or the Valar's activity in history, the more they are aware of their life as a 'mission' or 'vocation':

'I am commanded to go to the land of Mordor, and therefore I shall go.'99

\footnotetext{
${ }^{92} \operatorname{LotR} 1.3,84$.

${ }^{93} \operatorname{LotR} 1.7,126$

${ }^{94} \operatorname{LotR} 2.2,242$.

${ }^{95} \operatorname{LotR} 2.8,368$.

${ }^{96} \operatorname{Lot} R 2.9,390$.

${ }^{97} \operatorname{LotR} 4.5,681$. Cf. also 'I do not think that it is our part to drive him one way or the other. Nor do I think that we should succeed, if we tried. There are other powers at work far stronger' (LotR 2.10, 404). 'I cannot tell you how glad. Come along! It is plain that we were meant to go together' (LotR 2.10, 406).

${ }^{98} \operatorname{LotR} 3.3,457$.

${ }^{99} \operatorname{LotR} 4.3,638$.
} 
[Sam to himself:] 'But you haven't put yourself forward; you've been put forward. And as for not being the right and proper person, why, Mr. Frodo wasn't, as you might say, nor Mr. Bilbo. They didn't choose themselves.' 100

'I do not choose paths of peril, Éowyn. Were I to go where my heart dwells, far in the North I would now be wandering in the fair valley of Rivendell.' 101

Again, this kind of passages should be interpreted narratively (not symbolically or allegorically), as referring (almost meta-narratively) to the characters' awareness of the existence of an underlying narrative, designed by a hidden, divine Author.

And yet, all these references to the 'divine' narrative remain only allusive and elusive. Even the event which most patently betrays a divine intervention, Gandalf's 'reincarnation' (rather than 'resurrection') after his fall at Moria, remains unexplained in LotR:

[Gandalf recalling his battle with the Balrog:] 'I threw down my enemy, and he fell from the high place and broke the mountain-side where he smote it in his ruin. Then darkness took me, and I strayed out of thought and time, and I wandered far on roads that I will not tell. Naked I was sent back - for a brief time, until my task is done.' 102

A more open (but still incomplete) self-exegesis of this passage is found in Tolkien's letters, which allusively reveals that the agent of Gandalf's re-incarnation was in fact God Himself, Who is also secretly active in the story:

He [Gandalf] was sent by a mere prudent plan of the angelic Valar or governors; but Authority had taken up this plan and enlarged it, at the moment of its failure. 'Naked I was sent back'.... Sent back by whom, and whence? Not by the 'gods', whose business is only with this embodied world and its time; for he passed 'out of thought and time'. ${ }^{103}$

All this is already fascinating. But of course, one still needs to address the most important and interesting question: why did Tolkien so patently hide the 'divine narrative', while leaving glimpses of it? As Tolkien warned, a full answer to this question would 'take long to set out', ${ }^{104}$ but in what follows I will try to pave the way.

\footnotetext{
${ }^{100} \operatorname{LotR} 4.10,732$.

${ }^{101} \operatorname{LotR} 5.2,784$. Cf. also 'we must each go swiftly on the ways appointed to us' (LotR 4.5, 682). "'It is not madness, lady," he answered; "for I go on a path appointed"' (LotR 5.2, 775). 'I don't rightly know what I want: but I have something to do before the end, and it lies ahead, not in the Shire. I must see it through, sir, if you understand me' (LotR 1.4, 88).

${ }^{102} \operatorname{LotR} 3.5,502$.

${ }^{103}$ Letter 156, to R. Murray, SJ, 4 November 1954, 203.

104 Cf. Letter 211, 281: '[T]his would take long to set out: to explain indeed why there is practically no overt "religion," or rather religious acts or places or ceremonies among the "good" or anti-Sauron peoples in The Lord of the Rings.'
} 


\section{Reasons within the Secondary World: Cloaking and Freedom}

As for any question in Tolkien, and especially in relation to his poetics, there are two different levels to consider, one internal and one external to Tolkien's narrative universe; that is there are reasons belonging to the 'secondary' plane of Middle Earth, which yet symbolically (but not allegorically) represent Tolkien's own 'primary' views on literature and religion. ${ }^{105}$

\subsection{Respect for Created Freedom}

I will start with the former kind of answers, the 'internal' or 'secondary' ones. In this respect, an illuminating passage to give reason of the 'hiding of God' in LotR is again found in the chapter on the mission of the wizards (Istari), from Unfinished Tales.

For with the consent of Eru they sent members of their own high order, but clad in bodies as of Men.... And this the Valar did, desiring to amend the errors of old, especially that they had attempted to guard and seclude the Eldar by their own might and glory fully revealed; whereas now their emissaries were forbidden to reveal themselves in forms of majesty, or to seek to rule the wills of Men or Elves by open display of power. ${ }^{106}$

[B] ut they were forbidden to match his power with power, or to seek to dominate Elves or Men by force and fear. ${ }^{107}$

The cloaking of divine power, that of Gandalf and their own, is here revealed an intentional, momentous decision of the Valar, as Tolkien also highlights in his letters. ${ }^{108}$ The 'error of old' which the Valar try to amend by cloaking their power is one of the main events recounted in the Silmarillion, that is the Valar's summon of the Elves to an ancestral journey, from Middle Earth to the blessed realm of Valinor:

Then again the Valar were gathered in council, and they were divided in debate. For some, and of those Ulmo was the chief, held that the Quendi [i.e. the elves] should be left free to walk as they would in Middle-earth, and with their gifts of skill to order all the lands and heal their hurts. But the most part feared for the Quendi in the dangerous world amid the deceits of

\footnotetext{
105 On this see G. Pezzini, 'The Authors of Middle Earth: Tolkien and the Mystery of Literary Creation', The Journal of Inklings Studies 8, no 1 (2018), 48-51.

106 Unfinished Tales, 389.

107 Unfinished Tales, 391.

${ }^{108}$ Letter 156, to R. Murray, SJ, 4 November 1954, 202: 'At this point in the fabulous history the purpose was precisely to limit and hinder their exhibition of 'power' on the physical plane, and so that they should do what they were primarily sent for: train, advise, instruct, arouse the hearts and minds of those threatened by Sauron to a resistance with their own strengths; and not just to do the job for them.... [T] hey were not allowed to destroy them, or coerce them with any "divine" display of the powers they held over the physical world.... But they also realized that the Children of God must not be "dominated," though they would be specially susceptible to it.... It was because of this pre-occupation with the Children of God that the spirits so often took the form and likeness of the Children, especially after their appearance.'
} 
the starlit dusk; and they were filled moreover with the love of the beauty of the Elves and desired their fellowship. At the last, therefore, the Valar summoned the Quendi to Valinor, there to be gathered at the knees of the Powers in the light of the Trees for ever; and Mandos broke his silence, saying: 'So it is doomed.' From this summons came many woes that afterwards befell. ${ }^{109}$

This summon originated in the Valar's love for the elves, the first Children of Ilúvatar, and in their desire to share with the elves their divine reality; the summon was thus made with good intentions and yet it had disastrous effects, which resulted in the elves' rebellion (allegedly motivated by a craving for freedom), ${ }^{110}$ and eventually in a ban and exile from Valinor. But in what exactly did the Valar's error consist? In a disrespect of elvish freedom, however unintentional. By openly displaying their divine power to the elves, the Valar effectively forced them to come and join them in Valinor; they 'dominated' the elves, enforcing love on them out of fear or awe.

In Tolkien's 'secondary theology' there is thus a strict association between 'cloaking' and 'freedom'. 'Cloaking' or 'veiling' is a method chosen by the Valar (or rather imposed on them by Eru/Ilúvatar) to respect the freedom of elves (and humans), and oppose the Valar's temptation to 'domination'. 111

Cloaking does not, however, mean indifference or neglect: the Valar do continue to care about the inhabitants of Middle Earth, despite what may appear, and still guide, protect, and inspire them, in their resistance against Sauron, though not as openly as before. Moreover, in Tolkien's narrative the Valar still crave the love of the Elves, and ultimately still wish them to join them in their Blessed Land, in the West of Arda. However, this fellowship, this journey to the West where the Valar live, is no longer imposed, by their open power, but discretely (and covertly) proposed; after their ancestral 'mistake' the Valar have given up power, and learnt to use a 'gentler' method, more respectful of freedom, namely desire. In Tolkien's narratives, including LotR, desire for the divine is in fact a most important narrative element, whose true nature however remains 'hidden' from the readers and often from the characters themselves. ${ }^{12}$

This desire is narratively expressed as a vague 'latent desire for the Sea and for return into the West' ${ }^{113}$ All the 'high' elves of Noldorn race are characterized by this desire, but also

\footnotetext{
109 Silmarillion 3, 52.

${ }^{110} \mathrm{Cf}$. 'Fiercest burned the new flame of desire for freedom and wider realms in the eager heart of Fëanor' (Silmarillion 7, 68). Melkor/Morgoth is also deceivingly described as the 'Giver of freedom': cf. 'Melkor, Lord of All, Giver of Freedom, and he shall make you stronger than they' (Silmarillion, 272).

${ }^{111}$ On the freedom of the Children of Ilúvatar see T. Fornet-Ponse, "'Strange and free": On Some Aspects of the Nature of Elves and Men', Tolkien Studies 7 (2010), 67-89.

112 Cf. Silmarillion, 19.

113 Unfinished Tales, 237.
} 
'lower' characters, ${ }^{114}$ including the Hobbit Frodo, who is gradually introduced to this desire ${ }^{115}$ (against the Hobbits' default indifference or fear for the Sea and the West in general ${ }^{116}$ ), and eventually completely yields to it, sailing out of Middle Earth towards the blessed West. The ending of LotR, with Frodo embarking on a journey to the West, is topical in this respect, and effectively re-enacts the elves' ancestral summons to Valinor; in contrast with the Silmarillion, however, Frodo's journey is not enforced through an open revelation of power, as in the Silmarillion, but comes at the end of an 'education of desire', carried out above all by the Valar's secret agent in Middle Earth, Gandalf. In fact, Gandalf's task in Tolkien's narratives is not simply to guide the resistance again Sauron, but above all to 'rekindle' human desire, and ultimately the love for the divine.

'Take this ring, Master,' he said, 'for your labours will be heavy; but it will support you in the weariness that you have taken upon yourself. For this is the Ring of Fire, and with it you may rekindle hearts in a world that grows chill'. ${ }^{117}$

This 'rekindling' begins with an act of election: Gandalf's decision to enrol Bilbo in the quest of Erebor.

'They [the hobbits] had begun to forget: forget their own beginnings and legends, forget what little they had known about the greatness of the world. It was not yet gone, but it was getting buried: the memory of the high and the perilous. But you cannot teach that sort of thing to a whole people quickly. There was not time. And anyway you must begin at some point,

\footnotetext{
${ }^{114}$ Among whom Legolas in particular: cf. e.g. Galadriel's prophecy to Legolas: 'Beware of the Sea! If thou hearest the cry of the gull on the shore, | Thy heart shall then rest in the forest no more' (LotR 3.5, 503); and its later fulfilment: 'The Sea! Alas! I have not yet beheld it. But deep in the hearts of all my kindred lies the sealonging, which it is perilous to stir' (LotR 5.9, 873); 'To the Sea, to the Sea! The white gulls are crying, | The wind is blowing, and the white foam is flying. | West, west away, the round sun is falling. | Grey ship, grey ship, do you hear them calling, | The voices of my people that have gone before me?' (LotR 6.4, 956). Cf. Caldecott, Power of the Ring, 28-30.

${ }^{115}$ Cf. Frodo's first dream: 'A great desire came over him to climb the tower and see the Sea' (LotR 3.5, 108); 'Then he knew that it was not leaves, but the sound of the Sea far-off; a sound he had never heard in waking life, though it had often troubled his dreams (LotR 3.5, 503); 'Yes, something of everything, Sam, except the Sea,' Frodo had answered; and he repeated it now to himself: 'Except the Sea' (LotR 6.6, 986).

${ }^{116} \mathrm{Cf}$. '.... few Hobbits had ever seen or sailed upon the Sea, and fewer still had ever returned to report it. Most Hobbits regarded even rivers and small boats with deep misgivings, and not many of them could swim. And as the days of the Shire lengthened they spoke less and less with the Elves, and grew afraid of them, and distrustful of those that had dealings with them; and the Sea became a word of fear among them, and a token of death, and they turned their faces away from the hills in the west' (LotR Prologue, 7). Cf. also the clash between Sam and the 'mean' Ted: "They are sailing, sailing, sailing over the Sea, they are going into the West and leaving us," said Sam, half chanting the words, shaking his head sadly and solemnly. But Ted laughed. "Well, that isn't anything new, if you believe the old tales. And I don't see what it matters to me or you. Let them sail! But I warrant you haven't seen them doing it; nor anyone else in the Shire"' $(\operatorname{LotR} 1.2,45)$. And on the way back: 'I thought you'd gone off in one o' them ships you used to prattle about, sailing, sailing. What d'you want to come back for?' (LotR 6.8, 1017).

${ }^{117}$ LotR Appendix B, 1085.
} 
with some one person. I dare say he was "chosen" and I was only chosen to choose him; but I picked out Bilbo.' ${ }^{118}$

And indeed Bilbo's adventure begins with the rekindling of a latent desire, which is appropriately associated with another important divine entity, the stars.

As they sang the hobbit felt the love of beautiful things made by hands and by cunning and by magic moving through him.... Then something Tookish woke up inside him, and he wished to go and see the great mountains, and hear the pine-trees and the waterfalls, and explore the caves, and wear a sword instead of a walking-stick. He looked out of the window. The stars were out in a dark sky above the trees. ${ }^{119}$

Gandalf is of course the mastermind of Bilbo's adventure and is thus implicitly characterized as the fire that rekindles the desire for the 'high', and thus ultimately for God; and yet all this in a discreet, veiled manner, always respectful of the characters' freedom. In this Gandalf thus epitomizes the Valar's attitude towards the inhabitants of Middle Earth: his 'cloaked' power goes hand in hand with his deep respect for the characters' freedom.

\subsection{The Freedom of the One}

Human, elvish, and hobbit freedom is thus an important 'secondary' factor explaining the 'hiding' of the 'divine narrative' in LotR; but there is more. In fact, that of elves and men is not the only kind of freedom which the Valar respect by cloaking their power. The deeper reason behind the Valar's respect for elvish and human freedom is the 'divine' origin of this very freedom, that is, the fact that these beings are the 'Children of Ilúvatar', the fruit of the freedom of the Creator Eru. As explained in the Silmarillion, the Valar had not part in the making of elves and men, and were amazed at their coming, perceiving in them 'the mind of Ilúvatar reflected anew' and learning 'a little more of his wisdom, ${ }^{\text {' }}{ }^{\text {. }}$

In fact, as Tolkien reveals in an important letter, the making and nature of the elves and men are 'the two chief secrets' of the Creator, and epitomize His retention of creative freedom in the history of the world.

The Knowledge of the Creation Drama was incomplete: incomplete in each individual 'god', and incomplete if all the knowledge of the pantheon were

\footnotetext{
118 Unfinished Tales, 331.

${ }^{119}$ Hobbit 1, 19-20.

${ }^{120} \mathrm{Cf}$. '[a]nd they saw with amazement the coming of the Children of Ilúvatar, and the habitation that was prepared for them; and they perceived that they themselves in the labour of their music had been busy with the preparation of this dwelling, and yet knew not that it had any purpose beyond its own beauty. For the Children of Ilúvatar were conceived by him alone; and they came with the third theme, and were not in the theme which Ilúvatar propounded at the beginning, and none of the Ainur had part in their making. Therefore when they beheld them, the more did they love them, being things other than themselves, strange and free, wherein they saw the mind of Ilúvatar reflected anew, and learned yet a little more of his wisdom, which otherwise had been hidden even from the Ainur' (Silmarillion, 18).
} 
pooled. For (partly to redress the evil of the rebel Melkor, partly for the completion of all in an ultimate finesse of detail) the Creator had not revealed all. The making, and nature, of the Children of God, were the two chief secrets. Here we meet among other things, the first example of the motive (to become dominant in Hobbits) that the great policies of world history, 'the wheels of the world', are often turned not by the Lords and Governors, even gods, but by the seemingly unknown and weak - owing to the secret life in creation, and the part unknowable to all wisdom but One, that resides in the intrusions of the Children of God into the Drama. ${ }^{121}$

The word 'secret' is key, as well as the notion of 'intrusion', which is recurrent in Tolkien's letters: in fact

the One retains all ultimate authority and...reserves the right to intrude the finger of God into the story that is to produce realities which could not be deduced even from a complete knowledge of the previous past, but which being real become part of the effective past for all subsequent time (a possible definition of a 'miracle'). According to the fable Elves and Men were the first of these intrusions, ${ }^{122}$ made indeed while the 'story' was still only a story and not 'realized'; they were not therefore in any sense conceived or made by the gods, the Valar, and were called the Eruhíni or 'Children of God', and were for the Valar an incalculable element. ${ }^{123}$

The idea of 'intrusion' is strictly associated with the creative freedom of Eru/Ilúvatar ${ }^{124}$, the one wholly free Will and Agent, who intervenes in the story', introducing 'new themes into the original design, which might therefore be unforeseen by many of the spirits in realization'. The Valar are the Lords of Arda, masterminds of its 'history', but they do know the things 'that lie still in the freedom of Ilúvatar'.

By hiding His plans from the Valar, and by analogy from everyone else, Eru/Ilúvatar affirms His own creative freedom, which goes well beyond the creation of His (free) Children. God's freedom is indeed also revealed in His free 'intrusion' in the narrative, in ways however which are always 'discrete, 'hidden' and 'secret', beyond the understanding of other beings, divine and not. The already mentioned 're-incarnation' of Gandalf is probably the most dramatic example of this kind of intrusion, but there are arguably many others.

In fact, from a narrative perspective, the freedom of God, who is the real Author(ity) beyond the stories, is above all enacted in His enhancement of the role played by seemingly irrelevant characters and events. As the passage quoted above explicitly reveals, the Creation of Elves

\footnotetext{
${ }^{121}$ Letter 131, to M. Waldman, late 1951, 146.

122 Cf. also Letter 156, to R. Murray, SJ, 4 November 1954, 203: 'It is at least there represented that the intrusion of Elves and Men into that story was not any part of theirs at all, but reserved: hence Elves and Men were called the Children of God.'

${ }^{123}$ Letter 131, to M. Straight, early 1956, 235.

${ }^{124}$ Cf. Letter 156, to R. Murray, SJ, 4 November 1954, 204: 'except perhaps by one of those strange exceptions to all rules and ordinances which seem to crop up in the history of the Universe, and show the Finger of God, as the one wholly free Will and Agent.'
} 
and Men is related to an important narrative motif, that is that 'the great policies of world history are turned by the seemingly unknown and weak'. This motif, which accordingly owes 'to the secret life of creation', is at the core of the narrative of LotR, and is often highlighted in the story, and associated in particular with Aragorn and the Hobbits. ${ }^{125}$ The Hobbits indeed are of course emblematic of this motif: iconically small and reserved, neglected or despised by the Wise and the Powerful, they will be revealed as heroes and saviours.

In this respect, it is not insignificant that the great lover of the Hobbits is the incarnate angel Gandalf, who, in contrast with Saruman and Sauron and the 'other powers', holds them in high esteem. Two features of the Hobbits in particular have attracted Gandalf's attention: their surprising unpredictability ${ }^{126}$ and their openness to pity and mercy for each other. ${ }^{127}$ Both of these features are by Tolkien explicitly associated with God, ${ }^{128}$ thus arguably suggesting a 'divine' preference for the Hobbits, recognized and embraced by Gandalf.

In fact, Gandalf's love for the hobbits is not ornamental: rather, Gandalf acknowledges that by a mysterious divine design the Hobbits have been 'chosen' as the instruments for the fulfilment of Eru's narrative. From a narrative perspective, Gandalf thus understands that the Hobbits' apparent irrelevance is a powerful asset against Sauron. The weakness of the Hobbits is thus a mere 'cloak' of the divine design that is underlying LotR, to confound the ways of the Powers. 'Cloaking' in general is an important narrative motif of Lot $R$, applied to many different characters and situations, including above all Aragorn, the 'hidden' and 'cloaked' king of Gondor. ${ }^{129}$ And as a key plot element, 'cloaking' is again purposefully chosen by Gandalf, and stigmatized by the personifications of a purely human wisdom.

\footnotetext{
${ }^{125} \mathrm{Cf}$. 'Suddenly Frodo noticed that a strange-looking weather-beaten man, sitting in the shadows near the wall, was also listening intently to the hobbit-talk.... A travel-stained cloak of heavy dark-green cloth was drawn close about him, and in spite of the heat of the room he wore a hood that overshadowed his face; but the gleam of his eyes could be seen as he watched the hobbits' (LotR 2.9, 156). 'This is the hour of the Shire-folk, when they arise from their quiet fields to shake the towers and counsels of the Great. Who of all the Wise could have foreseen it? Or, if they are wise, why should they expect to know it, until the hour has struck?' (LotR 2.2, 270). Gandalf to Aragorn: 'Turn your face from the green world, and look where all seems barren and cold' (LotR 6.5, 971).

${ }^{126} \mathrm{Cf}$. 'there is no Power in the world that knows all about hobbits. Among the Wise I am the only one that goes in for hobbit-lore: an obscure branch of knowledge, but full of surprises' (LotR 2.2, 48). 'Hobbits really are amazing creatures, as I have said before. You can learn all that there is to know about their ways in a month, and yet after a hundred years they can still surprise you at a pinch. I hardly expected to get such an answer, not even from you' (ib. p. 62). Cf. also 'YYou take after Bilbo,' said Gandalf. 'There is more about you than meets the eye, as I said of him long ago" (LotR 2.5, 328); and Treebeard's surprised reaction at his encounter with the hobbits: 'What are you, I wonder? I cannot place you. You do not seem to come in the old lists that I learned when I was young.' (LotR 3.4, 464), 'they [the Hobbits] are the first new thing under Sun or Moon that I have seen for many a long, long day. I shall not forget them.' (LotR 3.10, 586). On Hobbits as 'unforeseen characters', also from a meta-literary point of view, see Pezzini, 'Authors of Middle Earth' and cf. Nagy, 'On No Magic in Tolkien', 165. Another aspect of the Hobbits' attractiveness, as argued by B. Rosebury, Tolkien: A Cultural Phenomenon (New York: Palgrave Macmillan, 2003), 51, is their 'capacity for disinterested curiosity'.

${ }^{127} \mathrm{Cf}$. 'I began to have a warm place in my heart for them in the Long Winter,...that was the time to see their courage, and their pity one for another. It was by their pity as much as by their tough uncomplaining courage that they survived. I wanted them still to survive' (Unfinished Tales, 331).

${ }^{128}$ Cf. Letter 246, to E. Elgar, September 1963, 326: 'They tend to forget that strange element in the World that we call Pity or Mercy, which is also an absolute requirement in moral judgement (since absolute requirement in moral judgement (since it is present in the Divine nature). In its highest exercise it belongs to God.' Gandalf/Olorin himself, even before his mission to Middle Earth, was associated with pity (cf. 'Wisest of the Maiar was Olorin. He too dwelt in Lórien, but his ways took him often to the house of Nienna, and of her he learned pity and patience'; Silmarillion, 30-1). Cf. also Caldecott, Power of the Ring, 55-9.

${ }^{129}$ See above n. 121. Cloaking is also a key feature of the Fellowship of the Ring, especially after their stay at Lorien (cf. 'For each they had provided a hood and cloak', LotR 2.8, 370).
} 
'Now at this last we must take a hard road, a road unforeseen. There lies our hope, if hope it be.' 130

'Well, let folly be our cloak, a veil before the eyes of the Enemy!'131

'The only plan that is proposed to us is that a halfling should walk blindly into Mordor and offer the Enemy every chance of recapturing it for himself. Folly!' 132

All this folly and all this cloaking in LotR is ultimately dependent on and analogous to God's operation in the history of Middle Earth, which is always secret and cloaked, unforeseen and baffling to the reasoning of the Wise. ${ }^{133}$

In conclusion, by hiding their power from elves and humans the Valar respect God's freedom in two different but related senses: they (1) respect His freedom as embedded in His Children, freely created free by Him, and (2) abide with the 'methodology' of Eru/llúvatar in history in general, the 'life of creation', which is characterized by secrecy, unpredictability, and the enhancement of 'the unknown and the weak'.

\section{Reasons within the Primary World}

All the above considerations pertain the 'secondary' or 'internal' theology of Middle Earth, and yet they can also be construed as symbolically representing Tolkien's own, 'primary' theology. After all, the world of Middle Earth is not an imaginary world, but an imaginary historical moment of 'our habitation' in this planet, and the story of LotR is imaginatively 'supposed to take place in a period of the actual Old World of this planet'.

All the themes discussed above are traceable in Tolkien's non-literary writings, in reference to 'primary' views. For instance, Tolkien often talks about the operation of God's freedom in human history, through miraculous 'intrusions', ${ }^{134}$ as well as that Gods works in 'the dark in some forgotten corner', and for this reason 'no man can estimate what is really happening at the present sub specie aeternitatis' ${ }^{135}$ Similarly, the idea of a God embracing human weakness,

\footnotetext{
${ }^{130} \operatorname{LotR} 2.2,267$.

${ }^{131} \operatorname{LotR} 2.2,268$.

${ }^{132} \operatorname{LotR} 2.10,398$.

${ }^{133}$ Cf. Gandalf's words to Frodo 'do not be too eager to deal out death in judgement. For even the very wise cannot see all ends.' (LotR 1.2, 59, recalled at 4.1, 615); Elrond' statement: 'This is the hour of the Shire-folk, when they arise from their quiet fields to shake the towers and counsels of the Great. Who of all the Wise could have foreseen it? Or, if they are wise, why should they expect to know it, until the hour has struck?' (LotR 2.2, 271). See further Caldecott, Power of the Ring, 53.

${ }^{134}$ Cf. e.g. Letter 89, to C. Tolkien, 7-8 November 1944, 100: 'So Our Lord told them to give the little daughter of Jairus something to eat. So plain and matter of fact: for so miracles are. They are intrusions (as we say, erring) into real or ordinary life, but they do intrude into real life, and so need ordinary meals and other results.'

${ }^{135}$ Cf. Letter 79, to C. Tolkien, 22 August 1944, 91: 'Gloomy thoughts, about things one cannot really know anything [of]; the future is impenetrable especially to the wise; for what is really important is always hidden from contemporaries, and the seeds of what is to be are quietly germinating in the dark in some forgotten corner, while everyone is looking at Stalin or Hitler. No man can estimate what is really happening at the present sub specie aeternitatis. All we do know, and that to a large extent by direct experience, is that evil labours with vast power
} 
and revealing Himself through cloaked forms in order to respect human freedom and confound the plans of the Wise, is of course central to the Christian doctrine of Incarnation. It would be interesting to explore Tolkien's 'primary' theology in this respect; in this article, however, I will prefer to focus on the literary rather than doctrinal implications of Tolkien's 'poetics of cloaking'.

In fact, for Tolkien 'cloaking' is not primarily a theological category, but above all a literary one: Tolkien constantly describes his literary work as a 'cloaking' or 'veiling', and in particular containing elements of truth, but not explicitly and openly expressed.

I have purposely kept all allusions to the highest matters down to mere hints, perceptible only by the most attentive, or kept them under unexplained symbolic forms. ${ }^{136}$

[T] he author, the most modest... of men, whose instinct is to cloak such selfknowledge as he has, and such criticisms of life as he knows it, under mythical and legendary dress.... ${ }^{137}$

Since I have deliberately written a tale, which is built on or out of certain 'religious' ideas, but is not an allegory of them (or anything else) and does not mention them overtly, still less preach them, I will not now depart from that mode, and venture on theological disquisition for which I am not fitted. ${ }^{138}$

In fact, the category of 'cloaking' can be applied to Tolkien's literary work per se, which he describes as 'mythical and legendary dress' cloaking his knowledge of life and God. This allows us to talk of a proper 'poetics of veiling' or 'cloaking', whose features and implications I will investigate in this final section of my paper. Not surprisingly, one the main traits of this poetics is the one reflected in Tolkien's secondary world, namely the high concern for freedom.

\subsection{The freedom of the author: cloaking as a guarantee and a limit}

In fact, also in Tolkien's primary poetics, 'cloaking' is associated with 'freedom', and above all with the freedom of the sub-creator, the literary writer. ${ }^{139}$ The following passage is from a

and perpetual success - in vain: preparing always only the soil for unexpected good to sprout in. So it is in general, and so it is in our own lives.' Letter 69, to C. Tolkien, 14 May 1944, 80: 'One knows that there is always good: much more hidden, much less clearly discerned, seldom breaking out into recognizable, visible, beauties of word or deed or face - not even when in fact sanctity, far greater than the visible advertised wickedness, is really there. Cf. also 'Quite true, but not the whole truth. (The greater part of the truth is always hidden, in regions out of the reach of cynicism.)'

${ }^{136}$ Letter 156, to R. Beare, 14 October 1958, 201.

${ }^{137}$ Letter 163, to W. H. Auden, 7 June 1955, 211.

${ }^{138}$ Letter 211, to R. Beare, 14 October 1958, 283-4. Cf. also below, n. 151.

${ }^{139}$ On literary freedom in Tolkien see recently B. Saxton, 'Tolkien and Bakhtin on Authorship, Literary Freedom, and Alterity', Tolkien Studies 10 (2013), 167-83. On Tolkien's notion of sub-creation see C. Phelpstead, 'Mythmaking and Sub-creation' in Lee (ed.), Companion, 79-91, with bibliography; also Flieger, Green Suns and Faërie, part 1; B. Saxton, 'J.R.R. Tolkien, Sub-creation, and Theories of Authorship', Mythlore 31 (2014), 47-59; J.S. McIntosh, The Flame Imperishable: Tolkien, St. Thomas, and the Metaphysics of Faërie (Kettering, OH: Angelico Press, 2017). 
letter (153), eventually never sent, to a Catholic reader criticizing Tolkien for having 'overstepped the mark in metaphysical matters', that is for having created a world apparently incompatible with Catholic doctrine. Tolkien's response is a vigorous assertion of authorial freedom:

Are there any 'bounds to a writer's job' except those imposed by his own finiteness? No bounds, but the laws of contradiction, I should think.... I would claim...to have as one object the elucidation of truth, and the encouragement of good morals in this real world, by the ancient device of exemplifying them in unfamiliar embodiments, that may tend to 'bring them home'. ${ }^{140}$

The right to 'freedom' of the sub-creator is no guarantee among fallen men that it will not be used as wickedly as is Free Will. I am comforted by the fact that some, more pious and learned than I, have found nothing harmful in this Tale or its feignings as a 'myth'. ${ }^{141}$

The author's right 'to freedom', which is almost total in Tolkien's view, is strictly related to the 'feigning' or 'cloaking' function of 'sub-creation', which has 'freedom' as its 'fundamental function':

I should have said that liberation 'from the channels the creator is known to have used already' is the fundamental function of 'sub-creation', a tribute to the infinity of His potential variety, one of the ways in which indeed it is exhibited. $^{142}$

Free Will is derivative, and is only operative within provided circumstances; but in order that it may exist, it is necessary that the Author should guarantee it, whatever betides... So in this myth, it is 'feigned'...that He gave special 'sub-creative' powers to certain of His highest created beings: that is a guarantee that what they devised and made should be given the reality of Creation. ${ }^{143}$

Tolkien's considers his literary activity as an instance of sub-creation, whose fundamental function is 'liberation' of and from God's primary mode of creation; that is, one might say, to express truth in artistically 'cloaked' forms. ${ }^{144}$ In other words, according to Tolkien, God continues His creative freedom in history through the individual freedom of the artist, who has

\footnotetext{
${ }^{140}$ Letter 153, to P. Hastings, September 1954, 194.

141 Ibid.

142 Ibid., 188.

143 Ibid., 195.

${ }^{144}$ On sub-creation in Tolkien's theory and practice see in particular the collection of essays in D. Fimi and T. Honegger (edd.), Sub-creating Arda: World-building in J.R.R. Tolkien's Work, its Precursors, and its Legacies (Zurich and Bern: Walking Tree Publishers, 2019), esp. the chapters by Izzo, Nagy, and Vink.
} 
'no boundary' within his own sub-created world. To impose boundaries would be to limit the freedom of the author, and thus transitively the freedom of God, who has created and cherished that freedom. Sub-creation does in fact have truth as an aim, but a truth which must be 'feigned' in myth, exemplified in 'unfamiliar embodiments', that is 'cloaked: the total freedom of the artist resides in, depends on and is restricted to this very act of 'cloaking'. 'Cloaking' is thus both the guarantee and the limit of authorial freedom. To express truth in open, explicit, noncloaked forms would be in a sense to betray the artist's mission, and overstep his freedom, by interfering with God's activity in the primary world: 'Myth and fairy-story must, as all art, reflect and contain in solution elements of moral and religious truth (or error), but not explicit, not in the known form of the primary "real" world.' 145

\subsection{Applicability and fantastic recovery: the freedom of the reader}

The author's artistic freedom is not the only freedom at stake in Tolkien's poetics of 'cloaking'. Another important freedom is that of the reader, in two related senses.

First of all, 'cloaking' protects the reader's freedom from the author's 'domination'. A passage from Tolkien's introduction to LotR is revealing in this respect:

I cordially dislike allegory in all its manifestations, and always have done so since I grew old and wary enough to detect its presence. I much prefer history, true or feigned, with its varied applicability to the thought and experience of readers. I think that many confuse 'applicability' with 'allegory'; but the one resides in the freedom of the reader, and the other in the purposed domination of the author. ${ }^{146}$

The dichotomy 'freedom' and 'domination' is an important motif in the secondary world of Tolkien' novels, which is here associated with Tolkien's notorious aversion to allegory. The distinction between 'allegory' and the 'applicability' of 'myth' has confused many readers, and is at times blurred also in Tolkien scholarship. One of the discriminating factors between the two approaches is the different consideration of the reader's freedom: if in allegory, Tolkien contends, the author tries to 'dominate' his readers by tacitly indoctrinating them into his 'truths', and for him literature is like the honey smeared on the brim of a medicine glass (to paraphrase an ancient analogy); in contrast, the 'sub-creator' does not primarily aim to indoctrinate his readers, and for him literary 'cloaking' is not a rhetorical strategy with an external purpose, but a self-standing undertaking, aimed to entertain and 'move' his readers (not preach or catechize them). ${ }^{147}$

This does not mean that the sub-creator is not concerned with truth and the didactic edification of his readers.

\footnotetext{
${ }^{145}$ Letter 131, to M. Waldman, late 1951, 144.

${ }^{146}$ LotR Introduction, $\mathrm{xx}$.

${ }^{147}$ Cf. Letter 200, to R. Bowen, 25 June 1957, 260: 'But so do all attempts to 'explain' the images and events of a mythology. Naturally the stories come first.' Letter 329, to P.S. Szentmihály, October 1971, 414: ‘...the exact opposite of my procedure in The Lord of the Rings. I neither preach nor teach.' On Tolkien's concern for a nonChristian audience see in particular B.J. Birzer, J. R. R. Tolkien's Sanctifying Myth: Understanding Middle-earth (Wilmington, DE: ISI Books, 2002); Caldecott, Power of the Ring.
} 
But as it is - though it seems to have grown out of hand, so that parts seem (to me) rather revealed through me than by me - its purpose is still largely literary (and, if you don't boggle at the term, didactic). ${ }^{148}$

I would claim...to have as one object the elucidation of truth, and the encouragement of good morals in this real world, by the ancient device of exemplifying them in unfamiliar embodiments, that may tend to 'bring them home'. ${ }^{149}$

In fact, in order to be applicable to other people's lives, myth needs to contain elements of truth, that is 'universals', but the approach is different from that of allegory:

But in spite of this, do not let Rayner suspect 'Allegory'. There is a 'moral', I suppose, in any tale worth telling. But that is not the same thing. Even the struggle between darkness and light...is for me just a particular phase of history, one example of its pattern, perhaps, but not The Pattern; and the actors are individuals - they each, of course, contain universals, or they would not live at all, but they never represent them as such. Of course, Allegory and Story converge, meeting somewhere in Truth. So that the only perfectly consistent allegory is a real life; and the only fully intelligible story is an allegory. ${ }^{150}$

Tolkien's 'actors' are not allegorical characters, but rather 'individuals'; their 'universality' is cloaked under the idiosyncrasies of fully imagined individuals. In Tolkien's sub-creation 'cloaking' is indeed what distinguishes an allegory from a story: paraphrasing the above, one could say that for Tolkien allegory has an open and intentional didactic purpose, whereas in story 'truth' is fully embedded within the cloak of a literary code (the 'unfamiliar embodiment' of a sub-creation) and its primarily aesthetic purpose. All this is not a rhetorical strategy, but is related to Tolkien's deep respect for the freedom of the reader, who is discretely invited to 'apply' to his own life the religious and ethical 'universals' embodied 'under mythical and legendary dress'.

The second important sense, introduced in the above passage, in which literary 'cloaking' enhances the 'reader's freedom' is related to the notion of 'recovery'. As Tolkien explains at length in his essay 'On Fairy Stories', the greatest danger for (modern) humans is to become slaves of 'triteness', 'familiarity' or 'possessiveness', that is of an approach to reality which is possessive and devoid of wonder. ${ }^{151}$ This, as Tolkien says, is not the way 'we were meant to see' reality, and ultimately leads not only to a lack of beauty and enjoyment, but above all to a lack of knowledge of reality as 'creation'. The purpose of 'creative Fantasy' (or sub-creation) is to recover all these, by 'cloaking' them in unfamiliar, fantastic forms:

\footnotetext{
${ }^{148}$ Letter 153, to P. Hastings, September 1954, 189.

${ }^{149}$ Letter 153, to P. Hastings, September 1954, 194.

${ }^{150}$ Letter 108, to S. Unwin, 31 July 1947, 121.

${ }^{151}$ For an embodiment of this theme in the secondary world cf. Caldecott, Power of the Ring, 38-41.
} 
[W] need recovery. We should look at green again, and be startled anew (but not blinded) by blue and yellow and red. We should meet the centaur and the dragon, and then perhaps suddenly behold, like the ancient shepherds, sheep, and dogs, and horses - and wolves....

Recovery (which includes return and renewal of health) is a re-gaining regaining of a clear view. I do not say 'seeing things as they are' and involve myself with the philosophers, though I might venture to say 'seeing things as we are (or were) meant to see them' - as things apart from ourselves. We need, in any case, to clean our windows; so that the things seen clearly may be freed from the drab blur of triteness or familiarity - from possessiveness. $^{152}$

This recovery is equated to a liberation from the slavery of hard appearances, ${ }^{153}$ and from the 'drab blur of triteness or familiarity': the reader is in fact not only exposed to the intellectual domination of the author, but also to the slavery of his own intellectual biases, superficialities and ideologies.

\subsection{A heart-racking desire}

The way in which literary 'cloaking' preserves the reader's freedom, from both the author's and his own intellectual dominations, is through the enhancement of desire. Tolkien's concern for the reader's freedom explains another important implication of his poetics of 'cloaking', which is the evocation of desire. As we have seen, in Tolkien's secondary world the Valar's 'cloaking' of their power goes hand in hand with the enhancement in the elves of an unexplained, insatiate desire for the divine; this is how the Valar attract elves to their divine reality, while respecting their freedom. The same connection between 'cloaking' and 'desire' is traceable in Tolkien's primary poetics. I can here use again the important metaphor of 'glimpsing', which is recurrent in Tolkien self-criticism of his work, and can be best illustrated by the following passages, different but related.

[For this reason, the emotion] that moves me supremely and I find small difficulty in evoking [is] the heart-racking sense of the vanished past. A story must be told or there'll be no story, yet it is the untold stories that are most moving. I think you are moved by [the elves] because [they] convey a sudden sense of endless untold stories: mountains seen far away, never to be climbed, distant trees never to be approached - unless in Paradise. ${ }^{154}$

Part of the attraction of The L.R. is, I think, due to the glimpses of a large history in the background: an attraction like that of viewing far off an unvisited island, or seeing the towers of a distant city gleaming in a sunlit

\footnotetext{
152 'On Fairy Stories', 146.

${ }^{153} \mathrm{Cf}$. also 'For creative Fantasy is founded upon the hard recognition that things are so in the world as it appears under the sun; on a recognition of fact, but not a slavery to it' ('On Fairy Stories', 144).

${ }^{154}$ Letter 96, to C. Tolkien, 30 January 1945, 110.
} 
mist. To go there is to destroy the magic, unless new unattainable vistas are again revealed. ${ }^{155}$

This experience of distances vaguely perceivable and yet 'veiled' evokes in the reader a 'heart-racking' longing for something unattainable, which is at the heart of the attraction of LotR. This attraction to 'unattainable vistas' is achieved by 'revealing glimpses or fragments of light, but not its source', 'by cloaking but not preaching truth', 'by leaving stories incomplete', and 'the full picture implicit or unexplained', to paraphrase the various metaphors used by Tolkien. ${ }^{156}$ From a literary-technical point of view, this means to renounce saying everything, to make lavish use of omissions, lacunae, and allusions, and, more specifically, to omit (almost) all explicit connections between LotR and the 'large narrative' ${ }^{157}$

The attraction of incompleteness, of seeing things veiled or cloaked, is also an important motif in LotR, and is embodied in particular in the hobbit's fascination with the 'fragments' of these uncompleted Elvish stories:

As for reward for his [i.e. Frodo's] part, it is difficult to feel that his life would be complete without an experience of 'pure Elvishness', and the opportunity of hearing the legends and histories in full the fragments of which had so delighted him. ${ }^{158}$

\footnotetext{
${ }^{155}$ Letter 247, to C. Worskett, 20 September 1963, 333. On the 'past' in Tolkien's works see M.D.C. Drout, 'The Tower and the Ruin: The Past in J.R.R. Tolkien's Works', in H. Conrad-O'Briain and G. Hynes (eds.), Tolkien: The Forest and the City (Dublin: Four Courts Press, 2013), 175-90. Cf. also Caldecott, Power of the Ring, 1-3, 29-30, 119-20.

${ }^{156} \mathrm{Cf}$. Letter 211, 283: 'As far as I know it is merely an imaginative invention, to express, in the only way I can, some of my (dim) apprehensions of the world'. Letter 268, to A.P. Northey, 19 January 1965, 354: 'I feel it is better not to state everything (and indeed it is more realistic, since in chronicles and accounts of "real" history, many facts that some enquirer would like to know are omitted, and the truth has to be discovered or guessed from such evidence as there is.' Letter 281, to R. Unwin, 15 December 1965, 365: 'I would say, if saying such things did not spoil what it tries to make explicit, "by ordained individuals, inspired and guided by an Emissary to ends beyond their individual education and enlargement"'. Letter 144, to N. Mitchison, 25 April 1954, 174: 'As a story, I think it is good that there should be a lot of things unexplained (especially if an explanation actually exists); and I have perhaps from this point of view erred in trying to explain too much, and give too much past history. Letter 151, to H. Brogan, 18 September 1954, 185: 'If you want my opinion, a part of the "fascination" [of The Lord of the Rings] consists in the vistas of yet more legend and history, to which this work does not contain a full clue.' Letter 153, to P. Hastings, September 1954, 190: 'He does not know what "wizards" are, or whence they came (though I do, even if exercising my subcreator's right I have thought it best in this Tale to leave the question a "mystery," not without pointers to the solution).' On this see also M. Izzo, 'Worldbuilding and Mythopoeia in Tolkien and post-Tolkienian Fantasy Literature', in D. Fimi and T. Honegger (edd.), Sub-creating Arda: Worldbuilding in J.R.R. Tolkien's Work, its Precursors, and its Legacies (Zurich and Bern: Walking Tree Publishers, 2019), 31-55, M. Hausmann, 'Lyrics on Lost Lands: Constructing Lost Places through Poetry in J.R.R.. Tolkien's The Lord of the Rings', ibidem, 261-284.

${ }^{157}$ Cf. Letter 247, 334: 'There are, of course, quite a lot of links between The Hobbit and The L.R. that are not clearly set out. They were mostly written or sketched out, but cut out to lighten the boat:... I actually wrote in full an account of what really happened before Gandalf's visit to Bilbo and the subsequent "Unexpected Party," as seen by Gandalf himself. It was to have come in during a looking-back conversation in Minas Tirith; but it had to go, and is only represented in brief in App. A, pp. 358 to 360 .'

${ }^{158}$ Letter 246, to E. Elgar, September 1963, 328.
} 
'Fragmentation' however is not just a literary technique ${ }^{159}$ : as shown by the passages above, there are important theological implications behind this idea of 'cloaked' or 'incomplete' literature, which are related to the freedom of another important 'free' Agent, God Himself, whose freedom is also respected and acknowledged in literary cloaking. This will be the final concern of this article.

\subsection{Glimpsing the Light of God in uncomplete stories}

As we have seen, in Tolkien's 'secondary' universe the notion of literary 'incompleteness' or 'cloaking,' 'hiding,' or 'glimpsing' is strictly related to the divine, in two important senses. First, according to Tolkien's mythology, the creation and history of the world are described as the artistic work of God (Eru/llúvatar); the Valar and all other rational beings, in different order, collaborate and play a part in this drama, and yet they do not have a full picture of it. Eru hid the fullness of His design even from the Valar, leaving their knowledge of His drama incomplete in order to allow space for the free 'intrusion of His finger', and thus preserve His ongoing creative freedom. Second, the stories of Middle Earth are constantly described by Tolkien, internally and externally, as being inherently incomplete and fragmentary: the complete fruition of these stories is only possible in the Blessed Land of Valinor, where the Elves live in full communion with the Valar, i.e. with the Divine. The same view is affirmed by Tolkien also on the primary level: "There is a place called "heaven" where the good here unfinished is completed; and where the stories unwritten, and the hopes unfulfilled, are continued.' 160

What connects these two outlooks on narrative 'incompleteness' is the idea of God as the supreme story-teller, that is as the only Author of the complete and fully satisfying Story. ${ }^{161}$ The creative activity of human story-tellers is analogous to that of God (i.e. it is 'sub-creative'), but, given its non-divine, secondary nature, it can only produce incomplete, fragmentary and ultimately unsatisfying stories. At the same time, these secondary, incomplete stories draw life from the One Story of God: they are like fragments refracting the divine light of the One Story: because of this, these human (or elvish) stories are able both to evoke a heart-racking desire for the full vision of the light of God, partially reflected by it, and at times manage to convey 'glimpses' of its truth.

[The joy of the happy ending] denies (in the face of much evidence, if you will) universal final defeat and in so far is evangelium, giving a fleeting glimpse of Joy, Joy beyond the walls of the world, poignant as grief....

\footnotetext{
159 On 'fragmentation' or 'splintering' as a typical Tolkienian category see Flieger, Green Suns and Faërie; Pezzini, 'Authors of Middle Earth'. On omission and lacuna as common literary techniques in Western literature see e.g. N. Gardini, Lacuna: Saggi sul non Detto (Turin: Einaudi, 2014).

${ }^{160}$ Letter 45, to M. Tolkien, 9 June 1941, 55. For an embodiment of the same idea in Tolkien's secondary world cf. Letter 246, 328 (quoted above) and also e.g. the Ents' song: 'Together we will take the road that leads into the West, | And far away will find a land where both our hearts may rest' (LotR 3.4, 477).

${ }^{161}$ Cf. Letter 192, to A. Ronald, 27 July 1956, 253: 'The Other Power then took over: the Writer of the Story (by which I do not mean myself), "that one ever-present Person who is never absent and never named" (as one critic has said).'
} 
In such stories when the sudden 'turn' comes we get a piercing glimpse of joy, and heart's desire, that for a moment passes outside the frame, rends indeed the very web of story, and lets a gleam come through....

The peculiar quality of the 'joy' in successful Fantasy can thus be explained as a sudden glimpse of the underlying reality or truth. ${ }^{162}$

The view that human literature is a fragmented reflection of God's Literature, that is Creation, is at the core of Tolkien's essay 'On Fairy Stories' ${ }^{163}$ and the related poem Mythopoeia, ${ }^{164}$ and is also symbolically represented in his myth, and especially in the saga of the Silmarils, secondary artistic artefacts, which yet contain a divine light. The view explains why for Tolkien human stories are necessarily incomplete, why they can be completed only in Heaven or Valinor, and also why incompleteness as such is a powerful tool to evoke human desire for the divine.

An important implication of this view, which brings us back to my original question, is that human literature is by its nature unable to fully express the divine: the human mind can glimpse God's nature, but not rationalize it, and cannot express God in open, explicit, uncloaked terms. As seen above, sub-creation implies by its very nature a 'cloaking' of divine light in a human narrative framework, imperfect and fragmentary. For literature trying to express truth in uncloaked terms would be almost an offence against the nature of God and His creative freedom, which has not revealed everything to the human mind and cannot be fully contained by it. Moreover, it would be a betrayal of the vocation of literature, which is to evoke that 'heartracking' desire of things glimpsed, but not fully revealed. In fact, one might argue that for Tolkien trying to express God in literature would not just be an act of human hubris, but, above all, bad literature: to go to the top of the mountains is to destroy the magic, because the magic is in the desire, not in the secondary, finite object which generates it. ${ }^{165}$

The desire evoked in Tolkien's works is indeed a universal human seeking for something 'beyond the world', ${ }^{166}$ and (more or less) symbolically, the nostalgia for a place and time where the relationship between God and man was immediate and uncloaked, that is, 'Eden'. In fact, for Tolkien any desire, longing or nostalgia is ultimately an expression of the desire for 'Eden':

[C]ertainly there was an Eden on this very unhappy earth. We all long for it, and we are constantly glimpsing it: our whole nature at its best and least corrupted, its gentlest and most humane, is still soaked with the sense of 'exile'. If you come to think of it, your...obstinate memory of this 'home'

\footnotetext{
162 'On Fairy Stories', 153-5.

${ }^{163}$ See Flieger, Splintered Light, 21-32.

${ }^{164} \mathrm{Cf}$. also 'Man, Sub-creator, the refracted Light through whom is splintered from a single White to many hues, and endlessly combined in living shapes that move from mind to mind' ('On Fairy Stories', 144).

${ }^{165}$ On this paradoxical dynamic cf. Letter 131, 145: 'This desire is at once wedded to a passionate love of the real primary world and hence filled with the sense of mortality, and yet unsatisfied by it.'

${ }^{166} \mathrm{Cf}$. 'Therefore he willed that the hearts of Men should seek beyond the world and should find no rest therein' (Silmarillion 1, 41); cf. Caldecott, Power of the Ring, 12.
} 
of yours in an idyllic hour (when often there is an illusion of the stay of time and decay and a sense of gentle peace)... are derived from Eden. ${ }^{167}$

Art and literature are, for Tolkien, supreme forms in which nostalgia for 'Eden' and seeking for the transcendent are expressed and re-awakened. In this (and many other) respects, artistic sub-creations are analogous to (and continue) the Primary Creation of God, whose purpose for Tolkien is to generate in men the longing for a 'fellowship' with the Creator, who yet remains hidden and cloaked, in respect of the freedom of His creatures.

Tolkien's poetics of cloaking, and its technical implications such omission, lacuna, and 'veiling', are thus strictly related to his (Christian) views on the nature of (his) literature and the nature of God. Literature evokes the longing for God, by re-kindling human desire with tantalizing glimpses of infinite beauty; this is what gives literature its fascination, and also its value. This is of course a literary strategy, with many parallels in the greatest literature, but for Tolkien it is not just that. In fact, for Tolkien literature does not come only from the human mind, but involves the participation of God's creative power. Man is sub-creator but the light which his works refracts comes from the only Light of God: incompleteness and cloaking are means by which Tolkien acknowledges the mysterious (and perhaps mystic) origin of his subcreations. ${ }^{168}$

Leaving things incomplete, hidden, cloaked is also, for Tolkien, leaving the space for God's Freedom to enter and transfigure human artistic creation, integrating it into His history of creation. The participation of God's freedom in sub-creation is also another reason why literature must be 'cloaked' and incomplete, and why it should not be reduced to a doctrinal allegory. Literature for Tolkien is essentially a creative 'event', ${ }^{169}$ which, as any event, cannot be fully comprehended or expressed by human minds, because God has participated in it. Taking away the category of the 'event' by (allegedly) revealing or explaining everything would simply mean to reduce literature to a purely human undertaking (an 'allegory'), which would result in the failing of his attraction as well as of his mission, which is to rekindle the desire for God by collaborating to His creative activity. This was in fact Tolkien's life-long ambition and vocation, as he himself reveals in a letter to a friend, where he describes his literary work in terms very similar to the mission of Gandalf in LotR, to rekindle an old light, thanks to a 'spark of fire' which has been granted (and not independently conceived):

What I meant, and thought Chris meant, and am almost sure you meant, was that the TCBS had been granted some spark of fire - certainly as a body if not singly - that was destined to kindle a new light, or, what is the same thing, rekindle an old light in the world; that the TCBS was destined to testify for God and Truth in a more direct way even than by laying down its several lives in this war (which is for all the evil of our own side with large view good against evil). ${ }^{170}$

\footnotetext{
${ }^{167}$ Letter 96, to C. Tolkien, 30 January 1945, 110.

${ }^{168}$ Cf. Pezzini, 'Authors of Middle Earth'.

${ }^{169}$ Cf. Pezzini, 'Authors of Middle Earth'.

${ }^{170}$ Letter 5, to G.B. Smith, 12 August 1916, 10.
} 


\section{Conclusions and Epilogue}

In conclusion, Tolkien's poetics of cloaking, traceable above all in the hiding of the divine narrative in LotR, is related to freedom, 'the life of creation': (1) the freedom of the writer, who is called to express truth in the cloaked dresses of sub-creation; (2) the freedom of the reader, whose dormant 'religiosity', just like that of the hobbits, does not need preaching, but rather a 'rekindling' or 'recovery' of desire, ${ }^{171}$ brought about by 'unfamiliar', 'artistic' forms; and finally (3) the freedom of God, whom the author both respects and evokes by purposefully declining to say all in open, 'primary' terms. Tolkien's creative work has certainly to do with God, but not because it talks about Him, but because it is a vessel and fruit of His creative power, participating in the artistic event; this event happens through a mysterious interplay between the freedom of the writer and the freedom of God, for the love of the freedom of the reader. ${ }^{172}$

As a 'Tolkienian' epilogue, I here quote an etymology and a short poem from Unfinished Tales, which condense the topics and arguments discussed above. Both are related to Gandalf, that is, Olórin, the emissary of God in Middle Earth, and the 'symbol' of everything that I have argued in this article. I hope that the purpose and meaning of these will be clear enough to the reader (and yet, hopefully not completely so).

olo-s: vision, 'phantasy': Common Elvish name for 'construction of the mind' not actually (pre)existing in Eä apart from the construction, but by the Eldar capable of being by Art (Karmë) made visible and sensible. Olos is usually applied to fair constructions having solely an artistic object (i.e. not having the object of deception, or of acquiring power).... Olórin dwelt in Lórien in Valinor, and that though he loved the Elves, he walked among them unseen, or in form as one of them, and they did not know whence came the fair visions or the promptings of wisdom that he put into their hearts.... Olórin was 'counsellor of Irmo', and that in the hearts of those who hearkened to him awoke thoughts 'of fair things that had not yet been but might yet be made for the enrichment of Arda'.

Wilt thou learn the lore that was long secret of the Five that came from a far country? [...] How hast thou heard it the hidden counsel of the Lords of the West in the land of Aman? The long roads are lost that led thither, and to mortal Men Manwë speaks not. From the West-that-was a wind bore it to the sleeper's ear,

\footnotetext{
${ }^{171}$ C. Madsen, “'Light from an Invisible Lamp:” Natural Religion in The Lord of the Rings', in J. Chance (ed.), Tolkien and the Invention of Myth: A Reader (Lexington: University Press of Kentucky, 2004), 35-48.

${ }^{172}$ Cf. Pezzini, 'Authors of Middle Earth'.
} 
in the silences under night-shadow, when news is brought from lands forgotten and lost ages over seas of years

to the searching thought. Not all are forgotten by the Elder King. ${ }^{173}$

${ }^{173}$ Unfinished Tales, 396-7. 